\title{
Unearthing the microbial ecology of soil carbon cycling with DNA-SIP
}

\author{
Charles Pepe-Ranney and Ashley N Campbell ${ }^{*}{ }^{\dagger}$, Chantal Koechli ${ }^{\dagger}$, Sean Berthrong ${ }^{\ddagger}$, and Daniel H \\ Buckley ${ }^{\dagger} \$$ \\ $5^{*}$ These authors contributed equally to the manuscript and should be considered co-first authors, ${ }^{\dagger}$ School of Integrative \\ Plant Sciences, Cornell University, New York, USA, ${ }^{\ddagger}$ Department of Biological Sciences, Butler University, and $\S_{\text {corresponding author }}$
}

\section{Introductory Paragraph}

We explored the microbial contributions to decomposition using a sophisticated approach to DNA 10 Stable Isotope Probing (SIP). Our experiment evaluated the dynamics and ecological characteristics of functionally defined microbial groups that metabolize labile and structural $\mathrm{C}$ in soils. We added to soil a complex amendment representing 15 plant derived organic matter substituted with either ${ }^{13} \mathrm{C}$-xylose or ${ }^{13} \mathrm{C}$-cellulose to represent labile and structural $\mathrm{C}$ pools derived from abundant components of plant biomass. We found evidence for ${ }^{13} \mathrm{C}$-incorporation into DNA from ${ }^{13} \mathrm{C}$-xylose 20 and ${ }^{13} \mathrm{C}$-cellulose in 49 and 63 operational taxonomic units (OTUs), respectively. The types of microorganisms that assimilated ${ }^{13} \mathrm{C}$ in the ${ }^{13} \mathrm{C}$ xylose treatment changed over time being predominantly Firmicutes at day 1 followed by Bac25 teroidetes at day 3 and then Actinobacteria at day 7. These ${ }^{13} \mathrm{C}$-labeling dynamics suggest labile $\mathrm{C}$ traveled through different trophic levels. In contrast, microorganisms generally metabolized cellulose- $\mathrm{C}$ after 14 days and did not change to 30 the same extent in phylogenetic composition over time. Microorganisms that metabolized cellulose$\mathrm{C}$ belonged to poorly characterized but cosmopolitan soil lineages including Verrucomicrobia, Chloroflexi and Planctomycetes. We show that micro-

35 bial life history traits are likely to constrain the diversity of microorganisms that participate in the soil C-cycle.

stable isotope probing | structure-function relationships | soil microbial ecology | 16S rRNA gene

40 Abbreviations: C, Carbon; OTU, Operational Taxonomic Unit; SOM, Soil Organic Matter; BD, Buoyand Density; SIP, Stable Isotope Probing

\section{Introduction}

Soils worldwide contain 2,300 $\mathrm{Pg}$ of carbon (C) 45 which accounts for nearly $80 \%$ of the $\mathrm{C}$ present in the terrestrial biosphere [1, 2, Soil microorganisms drive $\mathrm{C}$ flux through the terrestrial biosphere and $\mathrm{C}$ respiration by soil microorganisms produces annually tenfold more $\mathrm{CO}_{2}$ than fossil fuel emis50 sions [3]. Despite the contribution of microorgan- isms to global C flux, many global $\mathrm{C}$ models ignore the diversity of microbial physiology [4 6] and we still know little about the ecophysiology of soil microorganisms. Characterizing the ecophysiology of 55 microbes that mediate $\mathrm{C}$ decomposition in soil has proven difficult due to their overwhelming diversity. Such knowledge should assist the development and refinement of global C models [7-10].

The degradative succession hypothesis is a sim60 ple framework that explains the impact of microbial ecophysiology on the decomposition of plant biomass. Most plant $\mathrm{C}$ is comprised of cellulose (30-50\%) followed by hemicellulose (20-40\%), and lignin (15-25\%) 11. Hemicellulose, being the most 65 soluble, degrades in the early stages of decomposition. Xylans are often an abundant component of hemicellulose, and xylose is often the most abundant sugar in hemicellulose, comprising as much as $60-90 \%$ of xylan in some plants (e.g switch70 grass [12]). The degradative succession hypothesis posits that fast growing organisms proliferate in response to the labile fraction of plant biomass such as sugars [13, 14] followed by slow growing organisms that target structural $\mathrm{C}$ such as cel75 lulose 13 . Evidence to support the degradative succession hypothesis comes from observing soil respiration dynamics and characterizing microorganisms cultured at different stages of decomposition. Microorganisms that consume labile $\mathrm{C}$ in 30 the form of sugars proliferate during the initial stages of decomposition [15, 16], and metabolize as much as $75 \%$ of sugar $\mathrm{C}$ during the first 5 days [17. In contrast, cellulose decomposition proceeds more slowly with rates increasing for approx85 imately 15 days while degradation continues for $30-$

.


90 days [17, 18. This hypothesis is generally consistent with the common categorization of soil microorganisms as either fast growing copiotrophs or slow growing oligotrophs 19. The degree to which 90 the degradative succession hypothesis presents an accurate model of litter decomposition has been questioned [20] 22 and it's clear that we need new approaches to dissect microbial contributions to $\mathrm{C}$ transformations in soils.

95 Though microorganisms mediate $80-90 \%$ of the soil C-cycle 23, 24], and microbial community composition can account for significant variation in C mineralization [25], terrestrial C-cycle models rarely consider the community composition of soils

100 26, 27. Variation in microbial community composition can be linked effectively to rates of soil processes when diagnostic genes for specific functions are available (e.g. nitrogen fixation [28]). However, the lack of diagnostic genes for describing 105 soil-C transformations has limited progress in characterizing the contributions of individual microorganisms to decomposition. Remarkably, we still lack basic information on the physiology and ecology of the majority of organisms that live in soils.

110 For example, contributions to soil processes remain uncharacterized for cosmopolitan bacterial phyla in soil such as Acidobacteria, Chloroflexi, Planctomycetes, and Verrucomicrobia. These phyla combined can comprise $32 \%$ of soil microbial commu115 nities (based on surveys of the SSU rRNA genes in soil) [29, 30].

Nucleic acid stable-isotope probing (SIP) links genetic identity and activity without the need diagnostic genetic markers or cultivation and has ex-

120 panded our knowledge of microbial processes 31. Nucleic acid SIP has notable complications, however, including the need to add large amounts of labeled substrate 32, label dilution resulting in partial labeling of nucleic acids [32, the poten125 tial for cross-feeding and secondary label incorporation 33 , and variation in genome $\mathrm{G}+\mathrm{C}$ content 34. As a result, most applications of SIP have targeted specialized microorganisms (for instance, methylotrophs [35], syntrophs [36], or microorgan130 isms that target pollutants [37]). Exploring the soil-C cycle with SIP has proven to be more challenging because SIP has lacked the resolution necessary to characterize the specific contributions of individual microbial groups to the decomposition 135 of plant biomass. High throughput DNA sequencing technology, however, improves the resolving power of SIP 38. It is now possible to use far less isotopically labeled substrate resulting in more environmentally realistic experimental conditions.

140 It is also possible to sequence rRNA genes from numerous density gradient fractions across multiple samples thereby increasing the resolution of a typical nucleic acid SIP experiment [39]. We have employed such a high resolution DNA stable iso45 tope probing approach to explore the assimilation of both xylose and cellulose into bacterial DNA in an agricultural soil.

We added to soil a complex amendment representative of organic matter derived from fresh 50 plant biomass. All treatments received the same amendment but the identity of isotopically labeled substrates was varied between treatments. Specifically, we set up a control treatment where all components were unlabeled, a treatment with ${ }^{13} \mathrm{C}$ 55 xylose instead of unlabeled xylose, and a treatment with ${ }^{13} \mathrm{C}$-cellulose instead of unlabeled cellulose. Soil was sampled at days 1, 3, 7, 14, and 30 and we identified microorganisms that assimilated ${ }^{13} \mathrm{C}$ into DNA at each point in time. We designed the 160 experiment to test of the degradative succession hypothesis as it applies to soil bacteria, to identify soil bacteria that metabolize xylose and cellulose, and to characterize temporal dynamics of xylose and cellulose metabolism in soil.

\section{Results}

After adding the organic matter amendment to soil, we tracked the flow of ${ }^{13} \mathrm{C}$ from ${ }^{13} \mathrm{C}$-xylose or ${ }^{13} \mathrm{C}$-cellulose into microbial DNA over time using DNA-SIP (Figure S1). The amendment consisted 170 of compounds representative of plant biomass including cellulose, lignin, sugars found in hemicellulose, amino acids, and inorganic nutrients (see Supplemental Information (SI)). The amendment was added at $2.9 \mathrm{mg} \mathrm{C} \mathrm{g}^{-1}$ soil dry weight (d.w.), and 175 this comprised $19 \%$ of the total $\mathrm{C}$ in the soil. The cellulose-C (0.88 $\mathrm{mg} \mathrm{C} \mathrm{g}^{-1}$ soil d.w.) and xylose$\mathrm{C}\left(0.42 \mathrm{mg} \mathrm{C} \mathrm{g}^{-1}\right.$ soil d.w.) in the amendment comprised $6 \%$ and $3 \%$ of the total $\mathrm{C}$ in the soil, respectively. The soil microbial community respired $18065 \%$ of the xylose within one day and $29 \%$ of the added xylose remained in the soil at day 30 (Figure $\mathrm{S} 2$. In contrast, cellulose-C declined at a rate of approximately $18 \mu \mathrm{g} \mathrm{C} \mathrm{d}^{-1} \mathrm{~g}^{-1}$ soil d.w. and $40 \%$ of added cellulose- $\mathrm{C}$ remained in the soil at 185 day 30 (Figure S2).

Community-level signal of ${ }^{13} \mathrm{C}$-assimilation in relation to substrate and time. We assessed assimilation of ${ }^{13} \mathrm{C}$ into microbial DNA by comparing the SSU rRNA gene sequence composition of SIP 90 density gradient fractions between ${ }^{13} \mathrm{C}$ treatments and the unlabeled control (see Methods and SI). Our main focus is to identify evidence of isotope incorporation into the DNA of specific OTUs (as described below), but it is instructive to begin by 95 observing overall patterns of variance in the SSU rRNA gene sequence composition of gradient fractions. In the unlabeled control treatment, fraction density represented the majority of the variance in 
SSU rRNA gene composition (Figure 1). This re200 sult is expected because Genome $\mathrm{G}+\mathrm{C}$ content correlates positively with DNA buoyant density and influences SSU rRNA gene composition in gradient fractions 34. In contrast, isotope assimilation into DNA will cause variation in gene sequence com205 position between corresponding density fractions from controls and labeled treatments. For example, the SSU rRNA gene composition in gradient fractions from the ${ }^{13} \mathrm{C}$-cellulose treatment deviated from corresponding control fractions on days 14 210 and 30 and this difference was observed only in the high density fractions $\left(>1.7125 \mathrm{~g} \mathrm{~mL}^{-1}\right.$, Figure 1). Likewise, SSU rRNA gene composition in gradient fractions from the ${ }^{13} \mathrm{C}$-xylose treatment also deviated from corresponding control fractions 215 but on days 1,3 , and 7 as opposed to 14 and 30 (Figure 1). The ${ }^{13} \mathrm{C}$-cellulose and ${ }^{13} \mathrm{C}$-xylose treatments also differed from each other in corresponding high density gradient fractions indicating that 275 different microorganisms were labeled across time

220 these treatments (Figure 1). These results are generally consistent with predictions of the degradative succession hypothesis.

We can observe further differences in the pattern of isotope incorporation over time for each treat-

225 ment. For example the SSU rRNA gene sequence ${ }^{2}$ composition in the ${ }^{13} \mathrm{C}$-cellulose treatment was similar on days 14 and 30 in corresponding high density fractions indicating similar patterns of isotope incorporation into DNA on the days. In con230 trast, in the ${ }^{13} \mathrm{C}$-xylose treatment, the SSU rRNA 2 gene composition varied between days 1,3 , and 7 in corresponding high density fractions indicating different pattenrs of isotope incorporation into DNA on these days. In the ${ }^{13} \mathrm{C}$-xylose treatment on days 23514 and 40 the SSU gene composition was similar to 200 control on days 14 and 30 for corresponding high density fractions (Figure 1 indicating that ${ }^{13} \mathrm{C}$ was no longer detectable in bacterial DNA on these days for this treatment. These results show that 240 the dynamics of isotope incorporation into DNA varied considerably for organisms that assimilated $\mathrm{C}$ from either xylose or cellulose.

Temporal dynamics of OTU relative abundance in non-fractionated DNA from soil. We monitored 245 the soil microbial community over the course of the experiment by surveying SSU rRNA genes in nonfractionated DNA from the soil. The SSU rRNA gene composition of the non-fractionated DNA changed with time (Figure $\mathrm{S} 3 \mathrm{P}$-value $=0.023, \mathrm{R}^{2}$ $250=0.63$, Adonis test 40]). In contrast, the microbial community could not be shown to change with treatment (P-value 0.23, Adonis test) (Figure S3. The latter result demonstrates the substitution of

${ }^{13} \mathrm{C}$-labeled substrates for unlabeled equivalents 255 could not be shown to alter the soil microbial com- munity composition. Twenty-nine OTUs exhibited sufficient statistical evidence (adjusted P-value $<0.10$, Wald test) to conclude they changed in relative abundance in the non-fractionated DNA over 60 the course of the experiment (Figure S4). When SSU rRNA gene abundances were combined at the taxonomic rank of "class", the classes that changed in abundance (adjusted P-value $<0.10$, Wald test) were the Bacilli (decreased), Flavobacteria (de65 creased), Gammaproteobacteria (decreased), and Herpetosiphonales (increased) (Figure [S5). Of the 29 OTUs that changed in relative abundance over time, 14 putatively incorporated ${ }^{13} \mathrm{C}$ into DNA (see below and Figure S4). OTUs that likely assimilated ${ }^{13} \mathrm{C}$ from ${ }^{13} \mathrm{C}$-cellulose tended to increase in relative abundance with time whereas OTUs that assimilated ${ }^{13} \mathrm{C}$ from ${ }^{13} \mathrm{C}$-xylose tended to decrease (Figure S6). OTUs that responded to both substrates did not exhibit a consistent rela275 tive abundance response over time as a group (Figure $\mathrm{S} 4$ and $\mathrm{S} 6$.

Changes in the phylogenetic composition of ${ }^{13} \mathrm{C}$ labeled OTUs with substrate and time. If an OTU exhibited strong evidence for assimilating ${ }^{13} \mathrm{C}$ into so DNA, we refer to that OTU as a "responder" (see Methods and SI for our operational definition of "responder"). The SSU rRNA gene sequences produced in this study were binned into 5,940 OTUs and we assessed evidence of ${ }^{13} \mathrm{C}$-labeling from both ${ }_{25}^{13} \mathrm{C}$-cellulose and ${ }^{13} \mathrm{C}$-xylose for each OTU. Fortyone OTUs responded to ${ }^{13} \mathrm{C}$-xylose, 55 OTUs responded to ${ }^{13} \mathrm{C}$-cellulose, and 8 OTUs responded to both xylose and cellulose (Figure 2 Figure 3 . Figure S7, Table S1, and Table S2. The number 900 of xylose responders peaked at days 1 and 3 and declined with time. In contrast, the number of cellulose responders increased with time peaking at days 14 and 30 (Figure S8).

The phylogenetic composition of xylose respon295 ders changed with time (Figure 2 and Figure 4 ) and $86 \%$ of xylose responders shared $>97 \%$ SSU rRNA gene sequence identity with bacteria cultured in isolation (Table S1). On day 1, Bacilli OTUs represented $84 \%$ of xylose responders (Figure 4 ) and on the majority of these OTUs were closely related to cultured representatives of the genus Paenibacillus (Table S1, Figure 3). For example, "OTU.57" (Table S1, annotated as Paenibacillus, had a strong signal of ${ }^{13} \mathrm{C}$-labeling at day 1 coinciding with its 5 maximum relative abundance in non-fractionated DNA. The relative abundance of "OTU.57" declined until day 14 and "OTU.57" did not appear to be ${ }^{13} \mathrm{C}$-labeled after day 1 (Figure S9). On day 3, Bacteroidetes OTUs comprised $63 \%$ of xy10 lose responders (Figure 4) and these OTUs were closely related to cultured representatives of the Flavobacteriales and Sphingobacteriales (Table S1. 
Figure 3. For example, "OTU.14", annotated as a flavobacterium, had a strong signal for ${ }^{13} \mathrm{C}$ 315 labeling in the ${ }^{13} \mathrm{C}$-xylose treatment at days 1 and 3 coinciding with its maximum relative abundance in non-fractionated DNA. The relative abundance of "OTU.14" then declined until day 14 and did not show evidence of ${ }^{13} \mathrm{C}$-labeling beyond day 3 320 (Figure S9). Finally, on day 7, Actinobacteria OTUs represented $53 \%$ of the xylose responders (Figure 4) and these OTUs were closely related to cultured representatives of Micrococcales (Table S1. Figure 3p. For example, "OTU.4", anno325 tated as Agromyces, had signal for ${ }^{13} \mathrm{C}$-labeling in the ${ }^{13} \mathrm{C}$-xylose treatment on days 1,3 and 7 with the strongest evidence of ${ }^{13} \mathrm{C}$-labeling at day 7 and did not appear ${ }^{13} \mathrm{C}$-labeled at days 14 and 30 . The relative abundance of "OTU.4" in non-fractionated

330 DNA increased until day 3 and then declined until day 30 (Figure S9). Proteobacteria were also common among xylose responders at day 7 where they comprised $40 \%$ of xylose responder OTUs. Notably, Proteobacteria represented the majority (6 335 of 8) of OTUs that responded to both cellulose and xylose (Figure S7).

The phylogenetic composition of cellulose responders did not change with time to the same extent as the xylose responders. Also, in con340 trast to xylose responders, cellulose responders often were not closely related $(<97 \%$ SSU rRNA gene sequence identity) to cultured isolates. Both the relative abundance and the number of cellulose responders increased over time peaking at 345 days 14 and 30 (Figure 2 Figure S8, and Figure S6). Cellulose responders belonged to the Proteobacteria (46\%), Verrucomicrobia (16\%), Planctomycetes (16\%), Chloroflexi (8\%), Bacteroidetes (8\%), Actinobacteria (3\%), and Melainabacteria (1 350 OTU) (Table S2).

The majority $(85 \%)$ of cellulose responders outside of the Proteobacteria shared $<97 \%$ SSU rRNA gene sequence identity to bacteria cultured in isolation. For example, $70 \%$ of the Verrucomi-

355 crobia cellulose responders fell within unidentified Spartobacteria clades (Figure 3), and these shared $<85 \%$ SSU rRNA gene sequence identity to any characterized isolate. The Spartobacteria OTU "OTU.2192" exemplified many cellulose respon360 ders (Table S2, Figure S9). "OTU.2192" increased in non-fractionated DNA relative abundance with time and evidence for ${ }^{13}$ C-labeling of "OTU.2192" in the ${ }^{13} \mathrm{C}$-cellulose treatment increased over time with the strongest evidence at days 14 and 30 (Fig365 ure S9). Most Chloroflexi cellulose responders belonged to an unidentified clade within the Herpetosiphonales (Figure 3) and they shared $<89 \%$ SSU rRNA gene sequence identity to any characterized isolate. Characteristic of Chloroflexi cel370 lulose responders, "OTU.64" increased in relative abundance over 30 days and evidence for ${ }^{13} \mathrm{C}$ labeling of "OTU.64" in the ${ }^{13}$ C-cellulose treatment peaked days 14 and 30 (Figure S9). Bacteroidetes cellulose responders fell within the $C y$ 75 tophagales in contrast with Bacteroidetes xylose responders that belonged instead to the Flavobacteriales or Sphingobacteriales (Figure 3). Bacteroidetes cellulose responders included one OTU that shared $100 \%$ SSU rRNA gene sequence idenso tity to a Sporocytophaga species, a genus known to include cellulose degraders. The majority (86\%) of cellulose responders in the Proteobacteria were closely related ( $>97 \%$ identity) to bacteria cultured in isolation, including representatives of the 85 genera: Cellvibrio, Devosia, Rhizobium, and Sorangium, which are all known for their ability to degrade cellulose (Table S2). Proteobacterial cellulose responders belonged to Alpha (13 OTUs), Beta (4 OTUs), Gamma (5 OTUs), and Delta390 proteobacteria (6 OTUs).

Characteristics of cellulose and xylose responders. Cellulose responders, relative to xylose responders, tended to have lower relative abundance in nonfractionated DNA, demonstrated signal consistent with higher atom $\%{ }^{13} \mathrm{C}$ in labeled DNA, and had lower estimated rrn copy number (Figure 5. OTUs that assimilated $\mathrm{C}$ from either cellulose or xylose were also clustered phylogenetically (see below) indicating that these traits were not dispersed 400 randomly across bacterial species.

In the non-fractionated DNA, cellulose responders had lower relative abundance $\left(1.2 \times 10^{-3}\right.$ (s.d. $\left.3.8 \times 10^{-3}\right)$ ) than xylose responders $\left(3.5 \times 10^{-3}\right.$ (s.d. $\left.5.2 \times 10^{-3}\right)$ ) (Figure 4 P-value $=1.12 \times 10^{-5}$, 405 Wilcoxon Rank Sum test). Six of the ten most common OTUs observed in the non-fractionated DNA responded to xylose, and, seven of the ten most abundant responders to xylose or cellulose in the non-fractionated DNA were xylose responders.

DNA buoyant density (BD) increases in proportion to atom $\%{ }^{13} \mathrm{C}$. Hence, the extent of ${ }^{13} \mathrm{C}$ incorporation into DNA can be evaluated by the difference in $\mathrm{BD}$ between ${ }^{13} \mathrm{C}$-labeled and unlabeled DNA. We calculated for each OTU its mean BD 415 weighted by relative abundance to determine its "center of mass" within a given density gradient. We then quantified for each OTU the difference in center of mass between control gradients and gradients from ${ }^{13} \mathrm{C}$-xylose or ${ }^{13} \mathrm{C}$-cellulose treatments 420 (see SI for the detailed calculation, Figure S11. We refer to the change in center of mass position for an OTU in response to ${ }^{13} \mathrm{C}$-labeling as $\Delta \hat{B D}$. This value can be used to compare relative differences in ${ }^{13} \mathrm{C}$-labeling between OTUs. $\Delta \hat{B D}$ values, 425 however, are not comparable to the BD changes observed for DNA from pure cultures both because they are based on relative abundance in density 
gradient fractions (and not DNA concentration) and because isolated strains grown in uniform con430 ditions generate uniformly labeled molecules while OTUs composed of heterogeneous strains in complex environmental samples do not. Cellulose responder $\triangle \hat{B D}\left(0.0163 \mathrm{~g} \mathrm{~mL}^{-1}\right.$ (s.d. 0.0094)) was greater than that of xylose responders $(0.0097 \mathrm{~g}$ ${ }_{435} \mathrm{~mL}^{-1}$ (s.d. 0.0094)) (Figure 5. P-value $=1.8610 \mathrm{x}$ $10^{-6}$, Wilcoxon Rank Sum test).

We predicted the rrn gene copy number for responders as described 41. The ability to proliferate after rapid nutrient influx correlates positively 440 to a microorganism's rrn copy number [42. Cellulose responders possessed fewer estimated $\mathrm{rrn}$ copy numbers (2.7 (1.2 s.d.)) than xylose responders $(6.2$ (3.4 s.d.) $)\left(\mathrm{P}=1.878 \times 10^{-9}\right.$, Wilcoxon Rank Sum test, Figure 5 and Figure S10. Furthermore, 445 the estimated $r r n$ gene copy number for xylose responders was inversely related to the day of first response $\left(\mathrm{P}=2.02 \times 10^{-15}\right.$, Wilcoxon Rank Sum test, Figure S10,Figure 5.

We assessed phylogenetic clustering of ${ }^{13} \mathrm{C}$ 450 responsive OTUs with the Nearest Taxon Index (NTI) and the Net Relatedness Index (NRI) 43. 5 We also quantified the average clade depth of cellulose and xylose responders with the consenTRAIT metric 44]. Briefly, the NRI and NTI evaluate

455 phylogenetic clustering against a null model for the distribution of a trait in a phylogeny. The 5 NRI and NTI values are z-scores or standard deviations from the mean and thus the greater the magnitude of the NRI/NTI, the stronger the evi-

460 dence for clustering (positive values) or overdispersion (negative values). NRI assesses overall clus- 5 tering whereas the NTI assesses terminal clustering 45. The consenTRAIT metric is a measure of the average clade depth for a trait in a phylogenetic 465 tree. NRI values indicate that cellulose responders clustered overall and at the tips of the phylogeny (NRI: 4.49, NTI: 1.43) while xylose responders clustered terminally (NRI: -1.33, NTI: 2.69). The consenTRAIT clade depth for xylose and cel470 lulose responders was 0.012 and 0.028 SSU rRNA gene sequence dissimilarity, respectively. As ref- 5 erence, the average clade depth as inferred from genomic analyses or growth in culture is approximately 0.017, 0.013 and 0.034 SSU rRNA gene 475 sequence dissimilarity for arabinase (arabinose like xylose is a five $\mathrm{C}$ sugar found in hemicellulose), glu- ${ }_{53}$ cosidase and cellulase, respectively 44, 46]. These results indicate xylose responders form terminal clusters dispersed throughout the phylogeny while 480 cellulose responders form deep clades of terminally clustered OTUs.

\section{Discussion}

We highlight two key results with implications for understanding structure-function relationships in 45 soils, and for applying DNA-SIP in future studies of the soil-C cycle. First, cellulose responders were members of physiologically undescribed taxonomic groups with few exceptions. This suggests that we have much to learn about the diversity 490 of structural-C decomposers in soil before we can begin to assess how they are affected by climate change and land management. Second, the response to xylose was characterized by a succession in activity from Paenibacillus OTUs (day 1) 95 to Bacteroidetes (day 3) and finally Micrococcales (day 7 ). This activity succession was mirrored by relative abundance profiles and may mark trophic$\mathrm{C}$ exchange between these groups. While trophic exchange has been observed previously in DNASIP studies 35 most applications of DNA-SIP focus on proximal use of labeled substrates. However, with increased sensitivity, DNA-SIP is well suited to tracking $\mathrm{C}$ flows throughout microbial communities over time and is not limited only to 505 observing the entry point for a given substrate into the soil C-cycle. Trophic interactions will critically influence how the global soil-C reservoir will respond to climate change [4] but we know little of biological interactions among soil bacteria. 10 Often bacteria are cast as a single trophic level 48 but it may be appropriate to investigate the soil food web at greater granularity. Additionally, our results show that DNA-SIP results can change dramatically over time suggesting that multiple 5 time points are necessary to rigorously and comprehensively describe which microorganisms consume ${ }^{13} \mathrm{C}$-labeled substrates in nucleic acid SIP incubations.

Microorganisms that consumed ${ }^{13} \mathrm{C}$-cellulose 20 were seldom related closely to any physiologically characterized cultured isolates but were members of cosmopolitan phylogenetic groups in soil including Spartobacteria, Planctomycetes, and Chloroflexi. Often cellulose responders were less than $52590 \%$ related to their closest cultured relatives showing that we can infer little, if anything at all, of their physiology from culture-based studies. Notably, many Spartobacteria were among the cellulose responder OTUs. This is particularly interest30 ing as Spartobacteria are globally distributed and found in a variety of soil types [49. These lineages may play important roles in global cellulose turnover (please see SI note 1 for further discussion of the phylogenetic affiliation of cellulose respon535 ders).

In addition to taxonomic identity, we quantified four ecological properties of microorganisms that were actively engaged in labile and structural $\mathrm{C}$ decomposition in our experiment: (1) time of activ- 
540 ity, (2) estimated rrn gene copy number, (3) phylogenetic clustering, and (4) density shift in response to ${ }^{13} \mathrm{C}$-labeling. Labile $\mathrm{C}$ was consumed before 600 structural $\mathrm{C}$ and these substrates were consumed by different microorganisms (Figure 1). This was 545 expected and is consistent with the degradative succession hypothesis. Consumers of labile $\mathrm{C}$ had higher estimated $r r n$ gene copy number than struc- 6 tural $\mathrm{C}$ consumers (Figure 5). rrn copy number is positively correlated with the ability to resus550 citate quickly in response to nutrient influx 42 which may be the advantage that enabled xylose responders to rapidly consume xylose. Both xylose and cellulose responders were terminally clustered phylogenetically suggesting that the ability to use 555 these substrates was phylogenetically constrained. Although labile $\mathrm{C}$ consumption is generally considered to be mediated by a diverse set of microorganisms, we found that xylose responders at day 1 were mainly members of one genus, Paenibacil560 lus. Our results suggests that life-history traits such as the ability to resuscitate quickly and/or grow rapidly may be more important in determining the diversity of microorganisms that actually mediate a given process than the genomic poten565 tial for substrate utilization (see SI note 2 for further discussion with respect to soil-C modelling). And last, labile $\mathrm{C}$ consumers, in contrast to structural $\mathrm{C}$ consumers, had lower $\Delta \hat{B D}$ in response to ${ }^{13} \mathrm{C}$-labeling. This result suggests that labile ${ }_{570} \mathrm{C}$ consumers were generalists, assimilating $\mathrm{C}$ from a variety of sources both labeled and unlabeled, while structural $\mathrm{C}$ consumers were more likely to be specialists and more closely associated with $\mathrm{C}$ from a single source.

575 We propose that the temporal fluctuations in ${ }^{13} \mathrm{C}$-labeling in the ${ }^{13} \mathrm{C}$-xylose treatment are due to trophic exchange of ${ }^{13} \mathrm{C}$. Alternatively, the temporal dynamics could be caused by microorganisms tuned to different substrate concentrations

580 and/or cross-feeding. However, trophic exchange would explain well the precipitous drop in abundance of Paenibacillus after day 1 with subsequent ${ }^{13}$ C-labeling of Bacteroidetes at day 3 as well as the precipitous drop in abundance of Bacteroidetes 585 at day 3 followed by ${ }^{13} \mathrm{C}$-labeling of Micrococcales at day 7 . Trophic exchange could be enabled by mother cell lysis (in the case of spore formers such as Paenibacillus), viral lysis, and/or the direct indirect effects of predation. Bacteroidetes types 590 have been shown to become ${ }^{13} \mathrm{C}$-labeled after the addition of live ${ }^{13} \mathrm{C}$-labeled Escherichia coli to soil [50] indicating their ability to assimilate $\mathrm{C}$ from microbial biomass. In addition, the dominant OTU labeled in the ${ }^{13} \mathrm{C}$-xylose treatment from the $\mathrm{Mi}$ 595 crococcales shares $100 \%$ SSU rRNA gene sequence identity to Agromyces ramosus a known predator that feeds upon on many microorganisms includ- ing yeast and Micrococcus luteus [51. Agromyces are abundant microorganisms in many soils and no Agromyces ramosus was the most abundant xylose responder in our experiment - the fourth most abundant OTU in our dataset. It is notable however, that if Agromyces ramosus is acting as a predator in our experiment, the organism remains 05 unlabeled in response to ${ }^{13} \mathrm{C}$-cellulose which suggests that its activity may be specific for certain prey or for certain environmental conditions (see SI note 3 for further discussion of trophic $\mathrm{C}$ exchange). Climate change is expected to diminish 10 bottom-up controls on microbial growth increasing the importance on top-down biological interactions for mitigating positive climate change feedbacks 47. Currently the extent of bacterial predatory activity in soil, and its consequences for the soil C15 cycle and carbon use efficiency is largely unknown. Elucidating the identities of bacterial predators in soil will assist in assessing the implications of climate change on global soil-C storage.

Conclusion. Microorganisms govern C-transformations 620 in soil and thereby influence global climate but still we do not know the specific identities of microorganisms that carry out critical C transformations. In this experiment microorganisms from physiologically uncharacterized but cosmopolitan 625 soil lineages participated in cellulose decomposition. Cellulose responders included members of the Verrucomicrobia (Spartobacteria), Chloroflexi, Bacteroidetes and Planctomycetes. Spartobacteria in particular are globally cosmopolitan soil mi630 croorganisms and are often the most abundant Verrucomicrobia order in soil [49. Fast-growing aerobic spore formers from Firmicutes assimilated labile $\mathrm{C}$ in the form of xylose. Xylose responders within the Bacteroidetes and Actinobacteria ${ }_{635}$ likely became labeled by consuming ${ }^{13} \mathrm{C}$-labeled constituents of microbial biomass either by saprotrophy or predation. Our results suggest that cosmopolitan Spartobacteria may degrade cellulose on a global scale, decomposition of labile plant $\mathrm{C}$ may 640 initiate trophic transfer within the bacterial food web, and life history traits may act as a filter constraining the diversity of active microorganisms relative to those with the genomic potential for a given metabolism.

\section{Methods}

All code to take raw SSU rRNA gene sequencing reads to final publication figures and through all presented analyses is located at the following URL: https://github.com/chuckpr/CSIP_succession_ data_analysis.

DNA sequences are deposited on MG-RAST (Accession XXXXXXX). 
Twelve soil cores $(5 \mathrm{~cm}$ diameter x $10 \mathrm{~cm}$ depth) were collected from six sampling locations within 655 an organically managed agricultural field in Penn Yan, New York. Soils were sieved (2 mm), homogenized, distributed into flasks $(10 \mathrm{~g}$ in each $250 \mathrm{ml}$ flask, $\mathrm{n}=36$ ) and equilibrated for 2 weeks. We amended soils with a mixture containing $2.9 \mathrm{mg}$ ${ }_{660} \mathrm{C} \mathrm{g}^{-1}$ soil dry weight (d.w.) and brought soil to $50 \%$ water holding capacity. By mass the amendment contained $38 \%$ cellulose, $23 \%$ lignin, $20 \%$ xylose, $3 \%$ arabinose, $1 \%$ galactose, $1 \%$ glucose, and $0.5 \%$ mannose. $10.6 \%$ amino acids (made in house 665 based on Teknova C9795 formulation) and $2.9 \%$ Murashige Skoog basal salt mixture which contains macro and micro-nutrients that are associated with plant biomass (Sigma Aldrich M5524). This mixture approximates the molecular composi670 tion of switchgrass biomass with hemicellulose replaced by its constituent monomers 52. We set up three parallel treatments varying the isotopically labeled component in each treatment. The treatments were (1) a control treatment with all 675 unlabeled components, (2) a treatment with ${ }^{13} \mathrm{C}$ cellulose instead of unlabeled cellulose (synthesized as described in SI), and (3) a treatment with ${ }^{13} \mathrm{C}$ xylose (98 atom $\%{ }^{13} \mathrm{C}$, Sigma Aldrich) instead of unlabeled xylose. Other details relating to sub680 strate addition can be found in SI. Microcosms were sampled destructively at days 1 (control and xylose only), $3,7,14$, and 30 and soils were stored at $-80^{\circ} \mathrm{C}$ until nucleic acid extraction. The abbre- ${ }^{74}$ viation $13 \mathrm{CXPS}$ refers to the ${ }^{13} \mathrm{C}$-xylose treatment ${ }_{685}\left({ }^{13} \mathrm{C}\right.$ Xylose Plant Simulant), $13 \mathrm{CCPS}$ refers to the ${ }^{13} \mathrm{C}$-cellulose treatment, and $12 \mathrm{CCPS}$ refers to the control treatment.

We used DESeq2 (R package), an RNA-Seq differential expression statistical framework [53], to

690 identify OTUs that were enriched in high den- 750 sity gradient fractions from ${ }^{13} \mathrm{C}$-treatments relative to corresponding gradient fractions from control treatments (for review of RNA-Seq differential expression statistics applied to microbiome OTU

695 count data see 54). We define "high density gradient fractions" as gradient fractions whose density falls between 1.7125 and $1.755 \mathrm{~g} \mathrm{ml}^{-1}$. For each OTU, we calculates logarithmic fold change (LFC) and corresponding standard error for enrichment in 700 high density fractions of ${ }^{13} \mathrm{C}$ treatments relative to control. Subsequently, a one-sided Wald test was used to assess the statistical significance of LFC values with the null hypothesis that LFC was less than one standard deviation above the mean of all $705 \mathrm{LFC}$ values. We independently filtered OTUs prior to multiple comparison corrections on the basis of sparsity eliminating OTUs that failed to appear in at least $45 \%$ of high density fractions for a given comparison. P-values were adjusted for multiple 710 comparisons using the Benjamini and Hochberg method [55. We selected a false discovery rate of $10 \%$ to denote statistical significance.

See SI for additional information on experimental and analytical methods.

${ }_{5}$ Acknowledgements. The authors would like to acknowledge the assistance of John Christian Gaby and Mallory Choudoir in developing the method used to produce ${ }^{13} \mathrm{C}$-labeled cellulose. We would also like to thank Ruth Ley, Steve Zinder, Nel20 son Hairston, and Nick Youngblut for providing comments that were helpful in the development of this manuscript. Sander Hunter assisted with the microcosm set up. This material is based upon work supported by the Department of En25 ergy Office of Science, Office of Biological \& Environmental Research Genomic Science Program under Award Numbers DE-SC0004486 and DESC0010558. Manuscript preparation by Ashley N. Campbell was performed under the auspices of the 730 U.S. Department of Energy by LLNL under Contract DE-AC52-07NA27344.

\section{References}

1. Amundson R (2001) The carbon budget in soils. Annu Rev Earth Planet Sci 29(1): 535-562.

2. Batjes N-H (1996) Total carbon and nitrogen in the soils of the world. Eur J Soil Sci 47(2): 151-163.

3. Chapin F (2002) Principles of terrestrial ecosystem ecology. (Springer, New York).

4. Allison S-D, Wallenstein M-D, Bradford M-A (2010) Soilcarbon response to warming dependent on microbial physiology. Nat Geosci 3(5): 336-340.

5. Six J, Frey S-D, Thiet R-K, Batten K-M (2006) Bacterial and fungal contributions to carbon sequestration in agroecosystems. Soil Sci Soc Am J 70(2): 555

5 6. Treseder K-K, Balser T-C, Bradford M-A, Brodie E-L, Dubinsky E-A, Eviner V-T, et al. (2011) Integrating microbial ecology into ecosystem models: challenges and priorities. Biogeochemistry 109(1-3): 7-18.

7. Bradford M-A, Fierer N, Reynolds J-F (2008) Soil carbon stocks in experimental mesocosms are dependent on the rate of labile carbon, nitrogen and phosphorus inputs to soils. Funct Ecol 22(6): 964-974.

8. Neff J-C, Asner G-P (2001) Dissolved organic carbon in terrestrial ecosystems: synthesis and a model. Ecosystems 4(1): $29-48$

9. McGuire K-L, Treseder K-K (2010) Microbial communities and their relevance for ecosystem models: Decomposition as a case study. Soil Biol Biochem 42(4): 529-535.

10. Wieder W-R, Bonan G-B, Allison S-D (2013) Global soil carbon projections are improved by modelling microbial processes. Nat Clim Chang 3(10): 909-912.

11. Lynd L-R, Weimer P-J, van Zyl W-H, Pretorius I-S (2002) Microbial cellulose utilization: fundamentals and biotechnology. Microbiol Mol Biol Rev 66(3): 506-577.

65 12. Bunnell K, Rich A, Luckett C, Wang Y-J, Martin E, Carrier D-J (2013) Plant maturity effects on the physicochemical properties and dilute acid hydrolysis of switchgrass (panicum virgatum, 1.) hemicelluloses. ACS Sustain Chem Eng 1(6): 649-654.

13. Garrett S-D (1963) Soil Fungi and soil fertility. (Pergamon Press, New York)

14. Bremer E, Kuikman P (1994) Microbial utilization of $14 \mathrm{C}[\mathrm{U}]$ glucose in soil is affected by the amount and timing of glucose additions. Soil Biol Biochem 26(4): 511-517.

775 15. Garrett S-D (1951) Ecological groups of soil fungi: a survey of substrate relationships. New Phytol 50(2): 149-166.

16. Alexander M (1964) Biochemical ecology of soil microorganisms. Annual Rev Microbiol 18(1): 217-250.

17. Engelking B, Flessa H, Joergensen R-G (2007) Microbial use of maize cellulose and sugarcane sucrose monitored by 
changes in the $13 \mathrm{C} / 12 \mathrm{C}$ ratio. Soil Biol Biochem 39(8): 1888-1896.

18. Hu S, van Bruggen A-HC (1997) Microbial dynamics asso- 850 ciated with multiphasic decomposition of ${ }^{14} \mathrm{C}$-labeled cellulose in soil. Microb Ecol 33(2): 134-143.

19. Fierer N, Bradford M-A, Jackson R-B (2007) Toward an ecological classification of soil bacteria. Ecology 88(6): 1354-1364.

20. Kjöller A-H, Struwe S (2002) Fungal communities, succes-

790 sion, enzymes, and decomposition. Enzymes in the Environment (Marcel Dekker, New York), pp 306-324.

21. Frankland J-C (1998) Fungal succession - unravelling the unpredictable. Mycol Res 102(1): 1-15.

22. Osono $\mathrm{T}$ (2005) Colonization and succession of fungi during

795 decomposition of Swida controversa leaf litter. Mycologia 97(3): $589-597$

23. Coleman D-C, Crossley D-A (1996) fundamentals of soil ecology. (Academic Press, Waltham, Massachusetts).

24. Nannipieri P, Ascher J, Ceccherini M-T, Landi L, Pietramellara G, Renella G (2003) Microbial diversity and soil functions. Eur J Soil Sci 54(4): 655-670.

25. Strickland M-S, Lauber C, Fierer N, Bradford M-A (2009) Testing the functional significance of microbial community composition. Ecology 90(2): 441-451.

805 26. Zak D-R, Blackwood C-B, Waldrop M-P (2006) A molecular dawn for biogeochemistry. Trends Ecol Evol 21(6): 288295.

27. Reed H-E, Martiny J-BH (2007) Testing the functional sig- 87 nificance of microbial composition in natural communities. FEMS Microbiol Ecol 62(2): 161-170.

28. Hsu S-F, Buckley D-H (2009) Evidence for the functional significance of diazotroph community structure in soil. ISME J 3(1): 124-136.

29. Janssen P-H (2006) Identifying the dominant soil bacterial

815 taxa in libraries of $16 \mathrm{~S}$ rRNA and 16S rRNA genes. Appl Environ Microbiol 72(3): 1719-1728.

30. Buckley D-H, Schmidt T-M (2002) Exploring the diversity of soil - a microbial rainforest. Biodiversity of Microbial Life: Foundation of Earth's Biosphere. ed. Reysenbach A-L (Wiley, New York, New York), pp 183-208.

31. Chen Y, Murrell J-C (2010) When metagenomics meets stable-isotope probing: progress and perspectives. Trends Microbiol 18(4): 157-163.

32. Radajewski S, Ineson P, Parekh N-R, Murrell J-C (2000) Stable-isotope probing as a tool in microbial ecology. $\mathrm{Na}$ ture 403(6770): 646-649.

33. DeRito C-M, Pumphrey G-M, Madsen E-L (2005) Use of field-based stable isotope probing to identify adapted populations and track carbon flow through a phenol-degrading soil microbial community. Appl Environ Microbiol 71(12): 7858-7865.

34. Buckley D-H, Huangyutitham V, Hsu S-F, Nelson T-A (2007) Stable isotope probing with ${ }^{15} \mathrm{~N}$ achieved by disentangling the effects of genome $\mathrm{G}+\mathrm{C}$ content and isotope entangling the effects of genome $\mathrm{G}+\mathrm{C}$ content and isotope enrichment $3189-3195$.

35. Lueders T, Wagner B, Claus P, Friedrich M-W (2004) Stable isotope probing of rRNA and DNA reveals a dy- 905 namic methylotroph community and trophic interactions with fungi and protozoa in oxic rice field soil. Environmental Microbiology 6(1): 60-72.

36. Lueders T, Pommerenke B, Friedrich M-W (2004) Stableisotope probing of microorganisms thriving at thermodynamic limits: syntrophic propionate oxidation in flooded soil. Appl Environ Microbiol 70(10): 5778-5786.

37. DeRito C-M, Pumphrey G-M, Madsen E-L (2005) Use of field-based stable isotope probing to identify adapted pop- ulations and track carbon flow through a phenol-degrading soil microbial community. Appl Environ Microbiol 71(12): 7858-7865.

38. Aoyagi T, Hanada S, Itoh H, Sato Y, Ogata A, Friedrich M$\mathrm{W}$, et al. (2015) Ultra-high-sensitivity stable-isotope probing of rRNA by high-throughput sequencing of isopycnic centrifugation gradients. Environ Microbiol Rep 7(2): 282287.

39. Verastegui Y, Cheng J, Engel K, Kolczynski D, Mortimer S, Lavigne J, et al. (2014) Multisubstrate isotope labeling and metagenomic analysis of active soil bacterial communities. $m$ Bio 5(4): e01157-14.

60 40. Anderson M-J (2001) A new method for non-parametric multivariate analysis of variance. Austral Ecol 26(1): 3246 .

41. Kembel S-W, Wu M, Eisen J-A, Green J-L (2012) Incorporating $16 \mathrm{~S}$ gene copy number information improves estimates of microbial diversity and abundance. PLoS Comput Biol 8(10): e1002743.

42. Klappenbach J-A, Dunbar J-M, Schmidt T-M (2000) rRNA Operon copy number reflects ecological strategies of bacteria. Appl Environ Microbiol 66(4): 1328-1333.

43. Webb C-O (2000) Exploring the phylogenetic structure of ecological communities: an example for rain forest trees. Am Nat 156(2): 145-155.

44. Martiny A-C, Treseder K, Pusch G (2013) Phylogenetic conservatism of functional traits in microorganisms. ISME $J 7(4): 830-838$.

45. Evans S-E, Wallenstein M-D (2014) Climate change alters ecological strategies of soil bacteria. Ecol Lett 17(2): 155164 .

46. Berlemont R, Martiny A-C (2013) Phylogenetic distribution of potential cellulases in bacteria. Appl Environ Microbiol 79(5): 1545-1554.

47. Crowther T-W, Thomas S-M, Maynard D-S, Baldrian P Covey K, Frey S-D, et al. (2015) Biotic interactions mediate soil microbial feedbacks to climate change. Proceedings of the National Academy of Sciences 112(22): 7033-7038.

48. Moore J-C, Walter D-E, Hunt H-W (1988) Arthropod regulation of micro- and mesobiota in below-ground detrital food webs. Annu Rev Entomol 33(1): 419-435.

49. Bergmann G-T, Bates S-T, Eilers K-G, Lauber C-L, Caporaso J-G, Walters W-A, et al. (2011) The under-recognized dominance of Verrucomicrobia in soil bacterial communities. Soil Biol Biochem 43(7): 1450-1455

50. Lueders T, Kindler R, Miltner A, Friedrich M-W, Kaestner M (2006) Identification of bacterial micropredators distinctively active in a soil microbial food web. Appl Environ Microbiol 72(8): 5342-5348.

51. Casida L-E (1983) Interaction of Agromyces ramosus with other bacteria in soil. Appl Environ Microbiol 46(4): 881888 . Microbial utilization and mineralization of ${ }^{14} \mathrm{C}$ glucose added in six orders of concentration to soil. Soil Biol Biochem 40(8): 1981-1988.

53. Love M-I, Huber W, Anders S (2014) Moderated estimation of fold change and dispersion for RNA-seq data with DESeq2. Genome Biol 15(12): 550.

54. McMurdie P-J, Holmes S (2014) Waste not, want not: why rarefying microbiome data is inadmissible. PLoS Comput Biol 10(4): e1003531.

. Benjamini Y, Hochberg Y (1995) Controlling the false discovery rate: A practical and powerful approach to multiple testing. Journal of the Royal Statistical Society. Series B (Methodological) 57(1): 289-300. 
bioRxiv preprint doi: https://doi.org/10.1101/022483; this version posted October 7, 2015. The copyright holder for this preprint (which was not certified by peer review) is the author/funder, who has granted bioRxiv a license to display the preprint in perpetuity. It is made

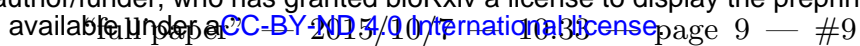
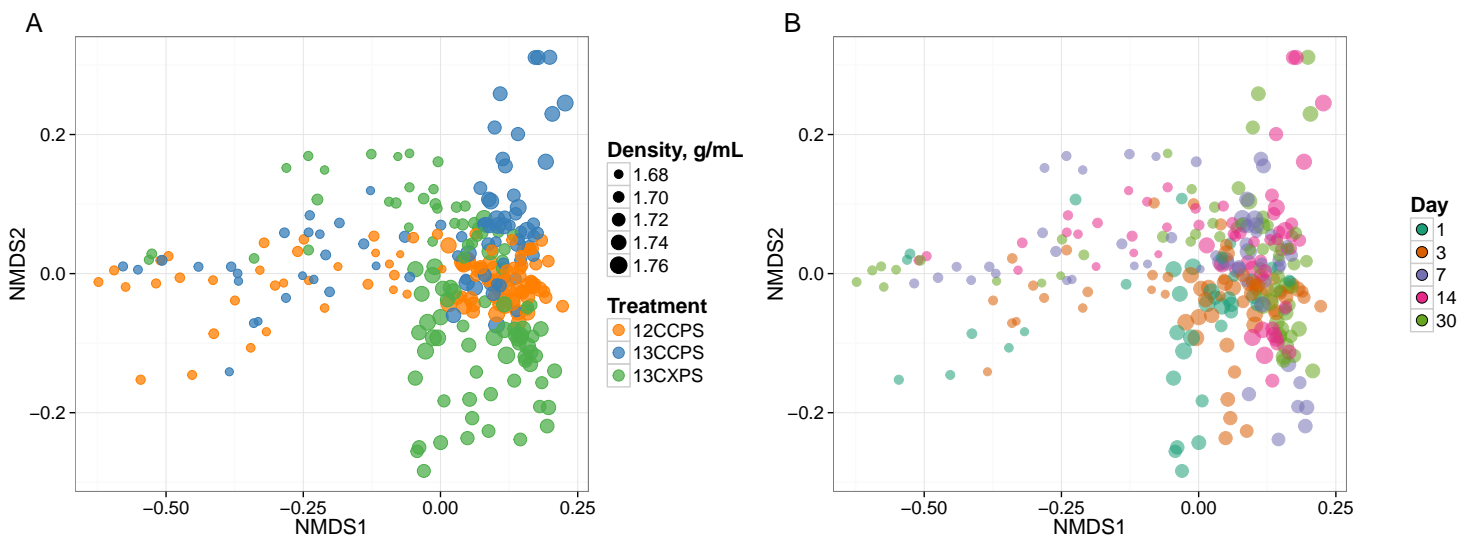

Fig. 1. NMDS ordination of SSU rRNA gene sequence composition in gradient fractions shows that variation between fractions is correlated with fraction density, isotopic labeling, and time. Dissimilarity in SSU rRNA gene sequence composition was quantified using the weighted UniFrac metric. SSU rRNA gene sequences were surveyed in twenty gradient fractions at each sampling point for each treatment (Figure S1). ${ }^{13}$ C-labeling of DNA is apparent because the SSU rRNA gene sequence composition of gradient fractions from ${ }^{13} \mathrm{C}$ and control treatments differ at high density. Each point on the NMDS plot represents one gradient fraction. SSU rRNA gene sequence composition differences between gradient fractions were quantified by the weighted Unifrac metric. The size of each point is positively correlated with density and colors indicate the treatment (A) or day (B).

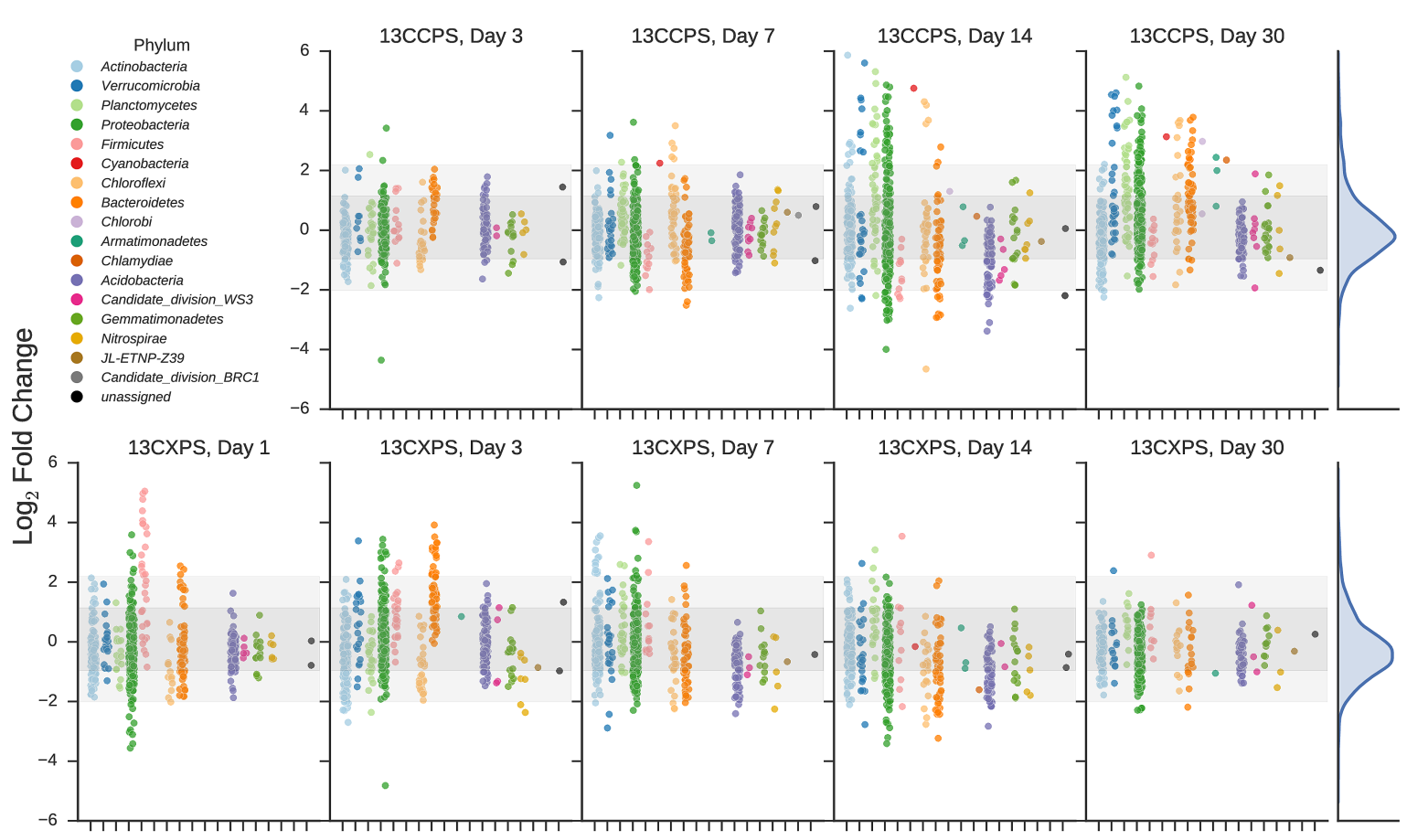

Phylum

Fig. 2. Enrichment of OTUs in either ${ }^{13} \mathrm{C}$-cellulose (13CCPS, upper panels) or ${ }^{13} \mathrm{C}$-xylose (13CXPS, bottom panels) treatments relative to control, expressed as LFC (see Methods). Each point indicates the LFC for a single OTU. High enrichment values indicate an OTU is likely ${ }^{13}$ C-labeled. Different colors represent different phyla and different panels represent different days. The final column shows the frequency distribution of LFC values in each row. Within each panel, shaded areas are used to indicate one standard deviation (dark shading) or two standard deviations (light shading) about the mean of all LFC values. 
bioRxiv preprint doi: https://doi.org/10.1101/022483; this version posted October 7, 2015. The copyright holder for this preprint (which was not certified by peer review) is the author/funder, who has granted bioRxiv a license to display the preprint in perpetuity. It is made

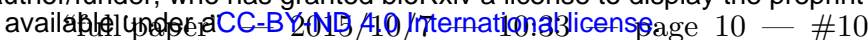
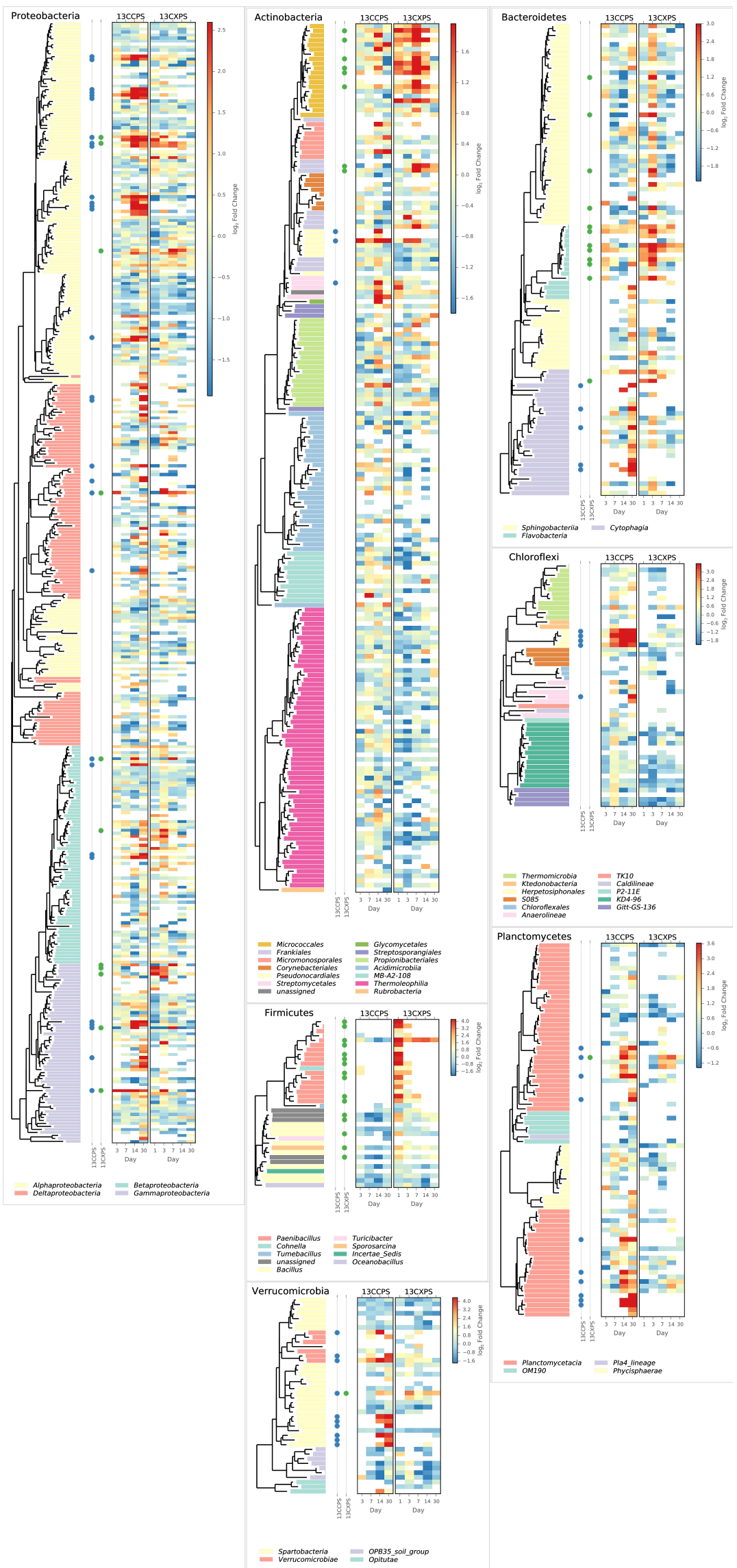

Fig. 3. Phylogenetic position of cellulose responders and xylose responders in the context of all OTUs that passed sparsity independent filtering criteria (see Methods). Only those phyla that contain responders are shown. Colored dots are used to identify xylose responders (green) and cellulose responders (blue). The heatmaps indicate enrichment in high density fractions relative to control (represented as LFC) for each OTU in response to both ${ }^{13} \mathrm{C}$-cellulose (13CCPS, leftmost heatmap) and ${ }^{13} \mathrm{C}$-xylose (13CXPS, rightmost heatmap) with values for different days in each heatmap column. High enrichment values (represented as LFC) provide evidence of ${ }^{13} \mathrm{C}$-labeled DNA. 
bioRxiv preprint doi: https://doi.org/10.1101/022483; this version posted October 7, 2015. The copyright holder for this preprint (which was not certified by peer review) is the author/funder, who has granted bioRxiv a license to display the preprint in perpetuity. It is made

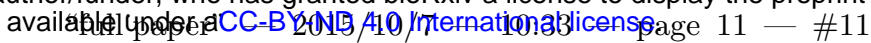
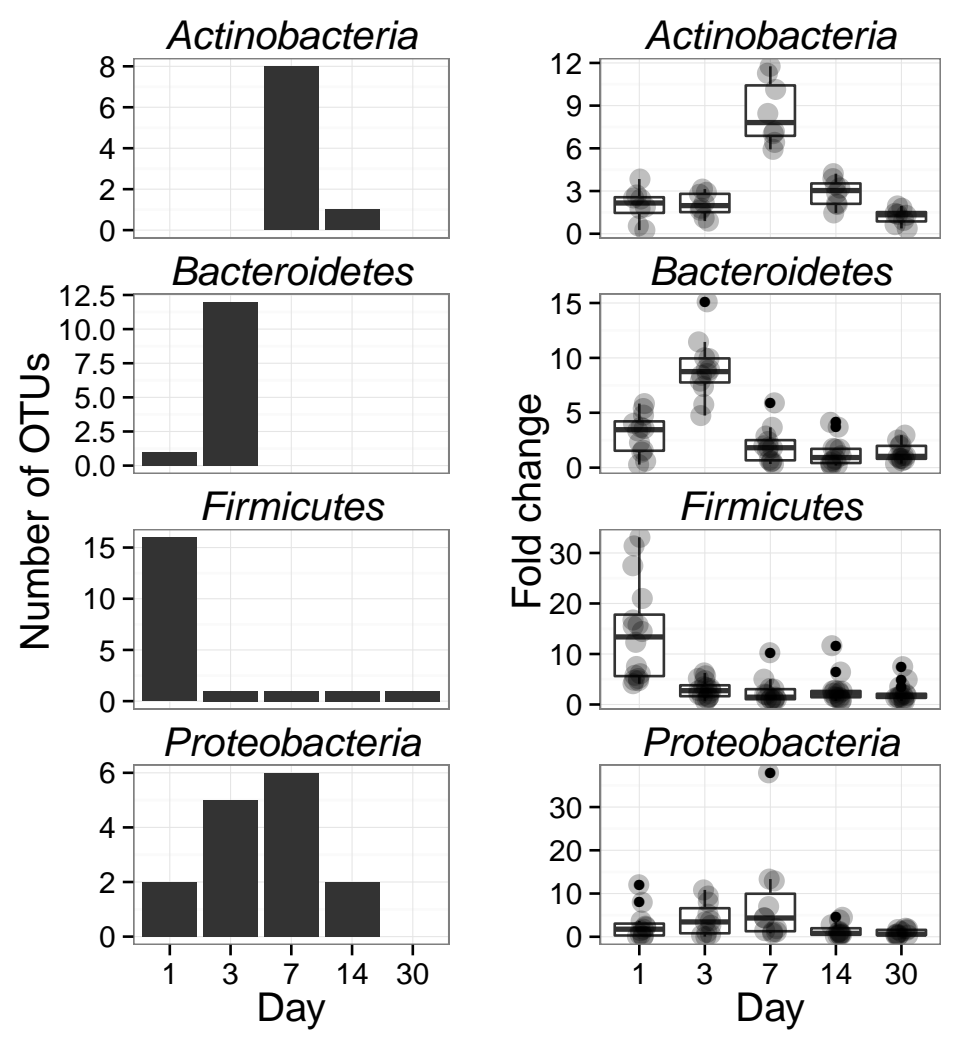

Fig. 4. Xylose reponders in the Actinobacteria, Bacteroidetes, Firmicutes exhibit distinct temporal dynamics of ${ }^{13} \mathrm{C}$-labeling. The left column shows counts of ${ }^{13} \mathrm{C}$-xylose responders in the Actinobacteria, Bacteroidetes, Firmicutes and Proteobacteria at days 1, 3, 7 and 30. The right panel shows OTU enrichment in high density gradient fractions (gray points, expressed as fold change) for responders as well as a boxplot for the distribution of fold change values (The box extends one interquartile range, whiskers extend 1.5 times the IR, and small dots are outliers (i.e. beyond 1.5 times the IR)). Each day in the right column shows all responders (i.e. OTUs that responded to xylose at any point in time). High enrichment values indicates OTU DNA is likely ${ }^{13} \mathrm{C}$-labeled.
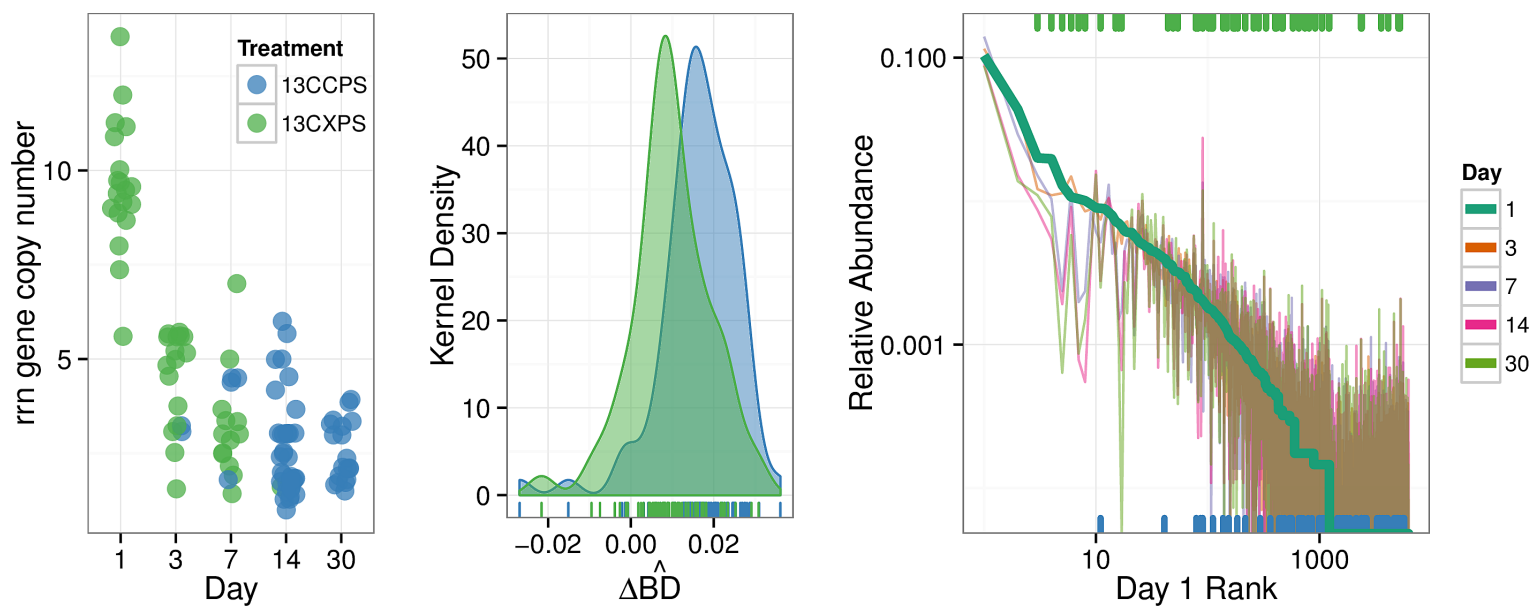

Fig. 5. Characteristics of xylose responders (green) and cellulose responders (blue) based on estimated $r r n$ copy number $(\mathrm{A}), \Delta \hat{B D}(\mathrm{~B})$, and relative abundance in non-fractionated DNA (C). The estimated $r r n$ copy number of all responders is shown versus time (A). Kernel density histogram of $\Delta \hat{B D}$ values shows cellulose responders had higher average $\triangle \hat{B D}$ than xylose responders indicating higher average atom $\%{ }^{13} \mathrm{C}$ in OTU DNA (B). The final panel indicates the rank relative abundance of all OTUs observed in the non-fractionated DNA (C) where rank was determined at day 1 (bold line) and relative abundance for each OTU is indicated for all days by colored lines (see legend). Xylose responders (green ticks) have higher relative abundance in non-fractionated DNA than cellulose responders (green ticks). All ticks are based on day 1 relative abundance. 
bioRxiv preprint doi: https://doi.org/10.1101/022483; this version posted October 7, 2015. The copyright holder for this preprint (which was not certified by peer review) is the author/funder, who has granted bioRxiv a license to display the preprint in perpetuity. It is made

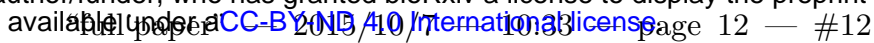

\section{Supplemental Figures and Tables}


bioRxiv preprint doi: https://doi.org/10.1101/022483; this version posted October 7, 2015. The copyright holder for this preprint (which was not certified by peer review) is the author/funder, who has granted bioRxiv a license to display the preprint in perpetuity. It is made availáblel
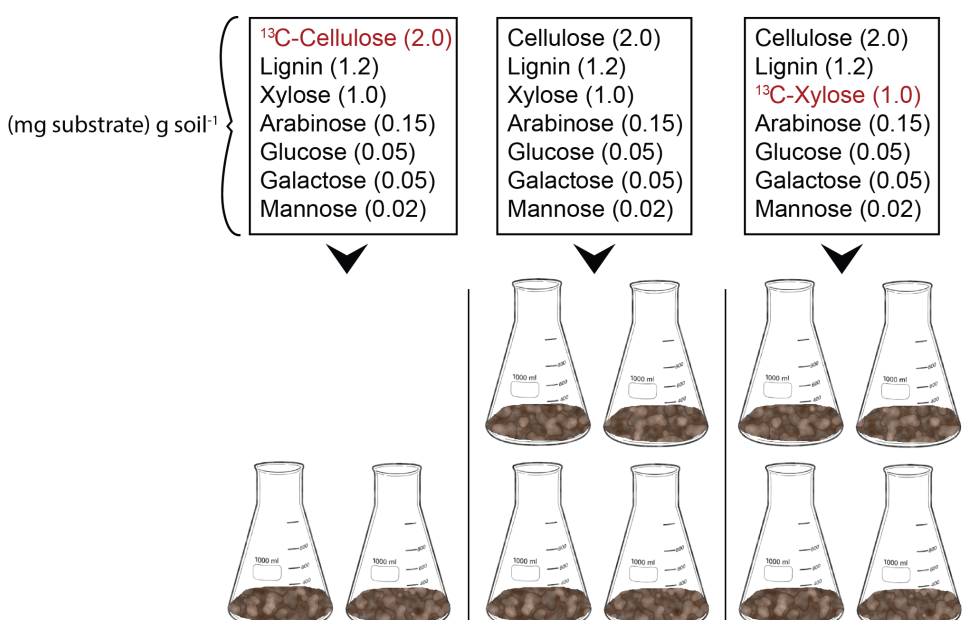

\section{Days}
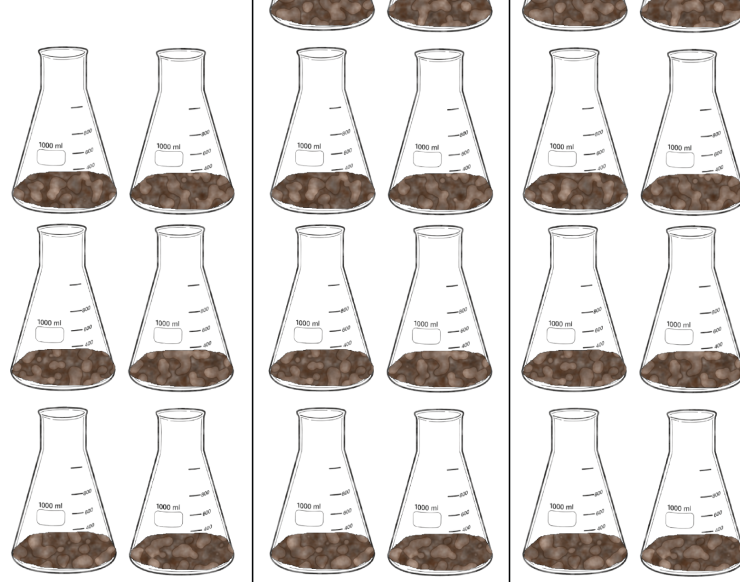

1
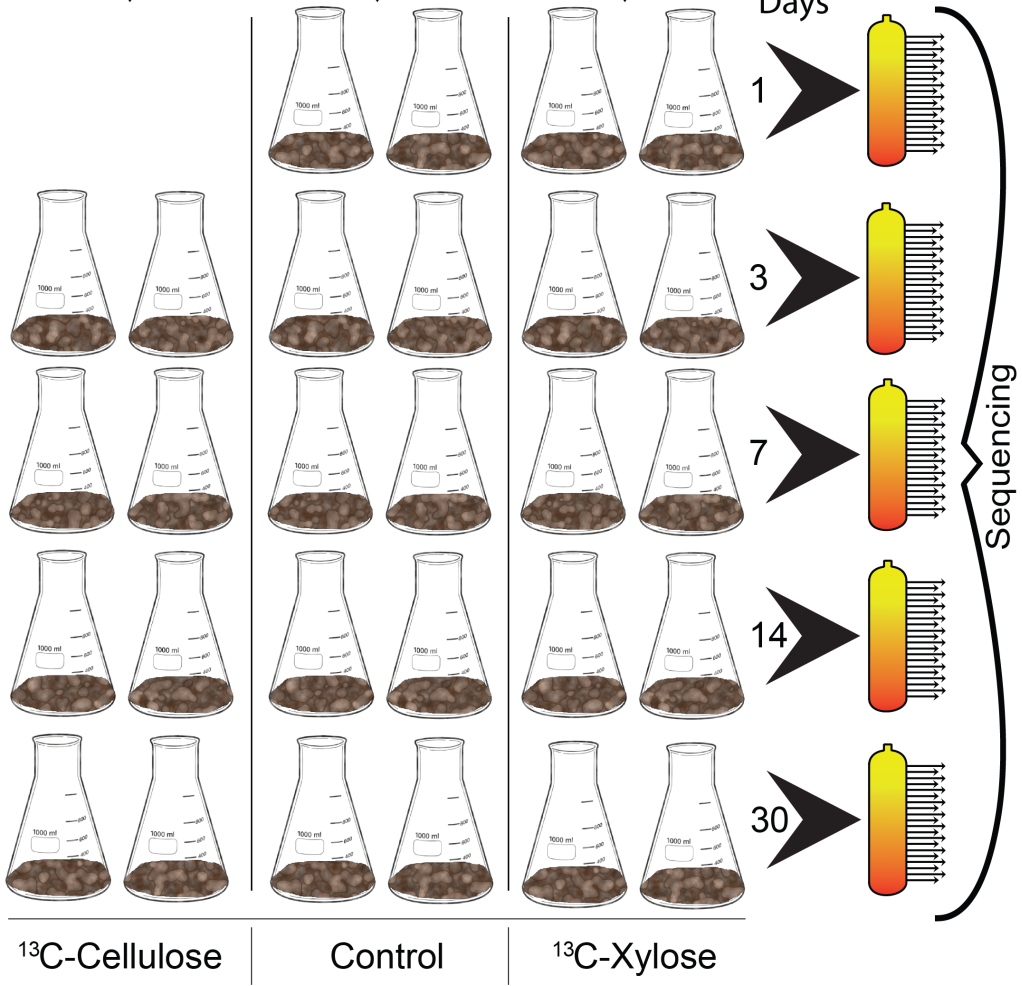

Fig. S1. We added a carbon mixture that contained inorganic salts and amino acids (not shown here) to each soil microcosm where the only difference between treatments was the ${ }^{13} \mathrm{C}$-labeled isotope (in red). At days $1,3,7,14$, and 30 replicate microcosms were destructively harvested for downstream molecular applications. DNA from each treatment and time $(\mathrm{n}=14)$ was subjected to $\mathrm{CsCl}$ density gradient centrifugation and density gradients were fractionated (orange tubes wherein each arrow represents a fraction from the density gradient). SSU rRNA genes from each gradient fraction were PCR amplified and sequenced. In addition, SSU rRNA genes were also PCR amplified and sequenced from non-fractionated DNA to represent the soil microbial community.

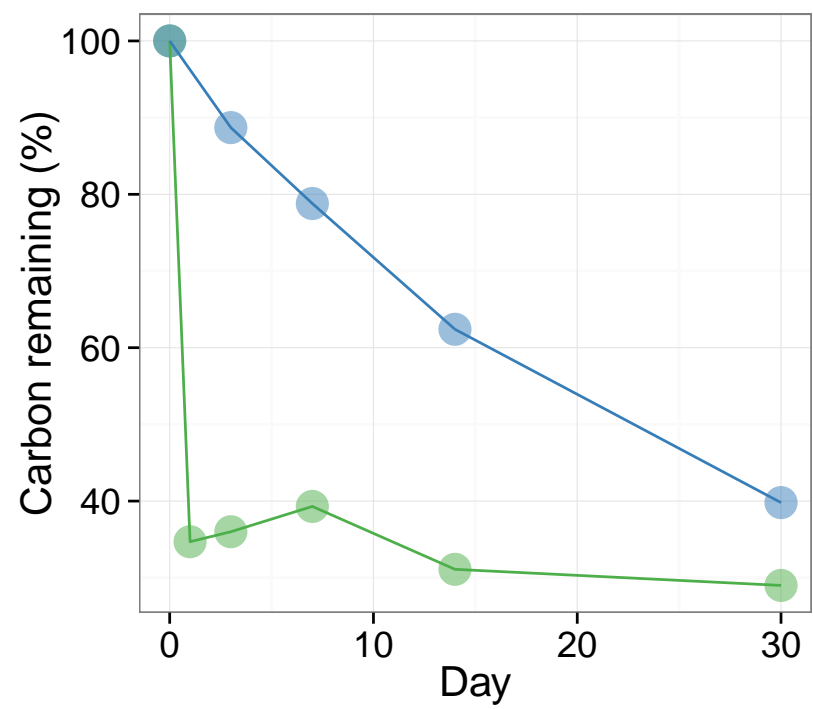

\section{Substrate}

xylose

cellulose

Fig. S2. The metabolization of ${ }^{13} \mathrm{C}$-xylose and ${ }^{13} \mathrm{C}$-cellulose is indicated by the percentage of the added ${ }^{13} \mathrm{C}$ that remains in soil over time. 
bioRxiv preprint doi: https://doi.org/10.1101/022483; this version posted October 7, 2015. The copyright holder for this preprint (which was not certified by peer review) is the author/funder, who has granted bioRxiv a license to display the preprint in perpetuity. It is made

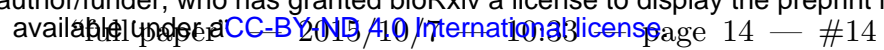
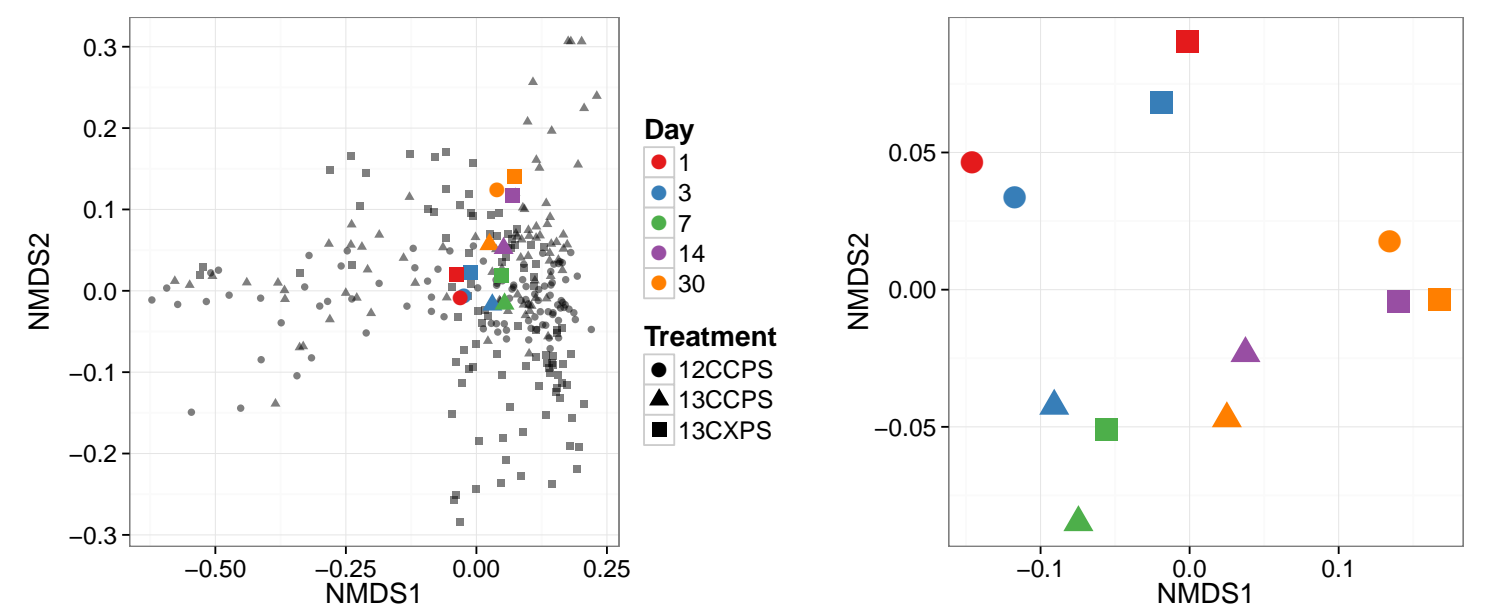

Fig. S3. NMDS analysis of SSU rRNA gene composition in non-fractionated DNA (colored points) indicates that isotopic labelling does not alter overall microbial community composition, microbial community composition in the soil microcosms changes over time, and variance in non-fractionated DNA is smaller than variance in fractionated DNA (black points). SSU rRNA gene sequences were determined for non-fractionated DNA from the unlabeled control, ${ }^{13} \mathrm{C}-\mathrm{xylose}$, and ${ }^{13} \mathrm{C}$-cellulose treatments over time (colors indicate time, different symbols used for different treatments). Distance in SSU rRNA gene composition was quantified with the UniFrac metric. The leftmost panel indicates NMDS of data from both non-fractionated and fractionated samples. The rightmost panel indicates NMDS of data only from non-fractionated DNA. Statistical analysis is presented in main text. 
bioRxiv preprint doi: https://doi.org/10.1101/022483; this version posted October 7, 2015. The copyright holder for this preprint (which was not certified by peer review) is the author/funder, who has granted bioRxiv a license to display the preprint in perpetuity. It is made

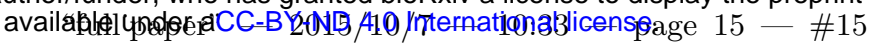

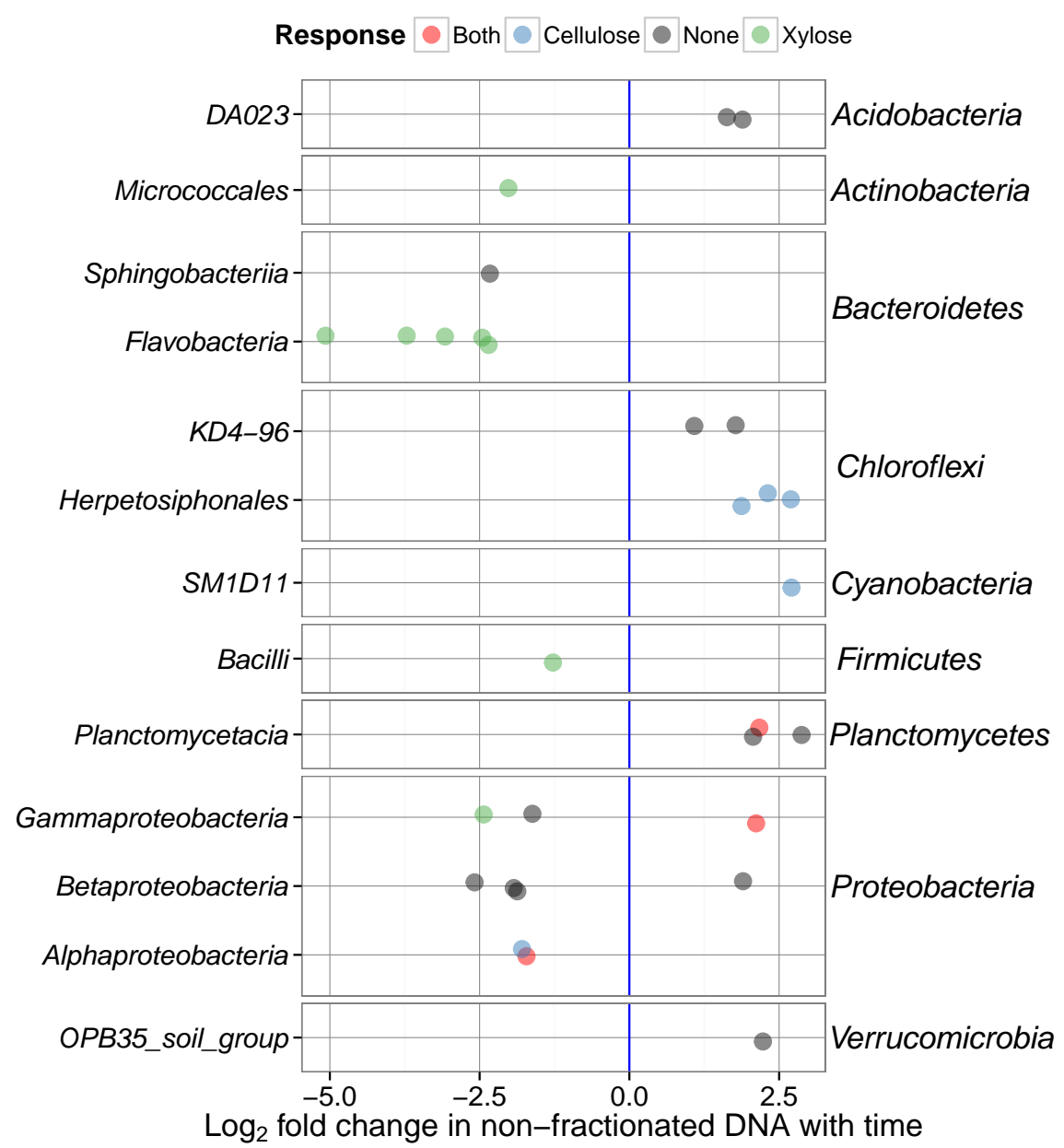

Fig. S4. Change in non-fractionated DNA relative abundance versus time (expressed as LFC) for OTUs that changed significantly over time (P-value $<0.10$, Wald test). Each panel shows one phylum (labeled on the right). The taxonomic class is indicated on the left. Colors represent results shown in Figure 2 and Figure 3. OTUs that responded to just xylose are shown in green, just cellulose in blue, and both xylose and cellulose in red. 
bioRxiv preprint doi: https://doi.org/10.1101/022483; this version posted October 7, 2015. The copyright holder for this preprint (which was not certified by peer review) is the author/funder, who has granted bioRxiv a license to display the preprint in perpetuity. It is made

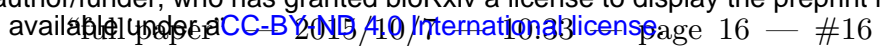

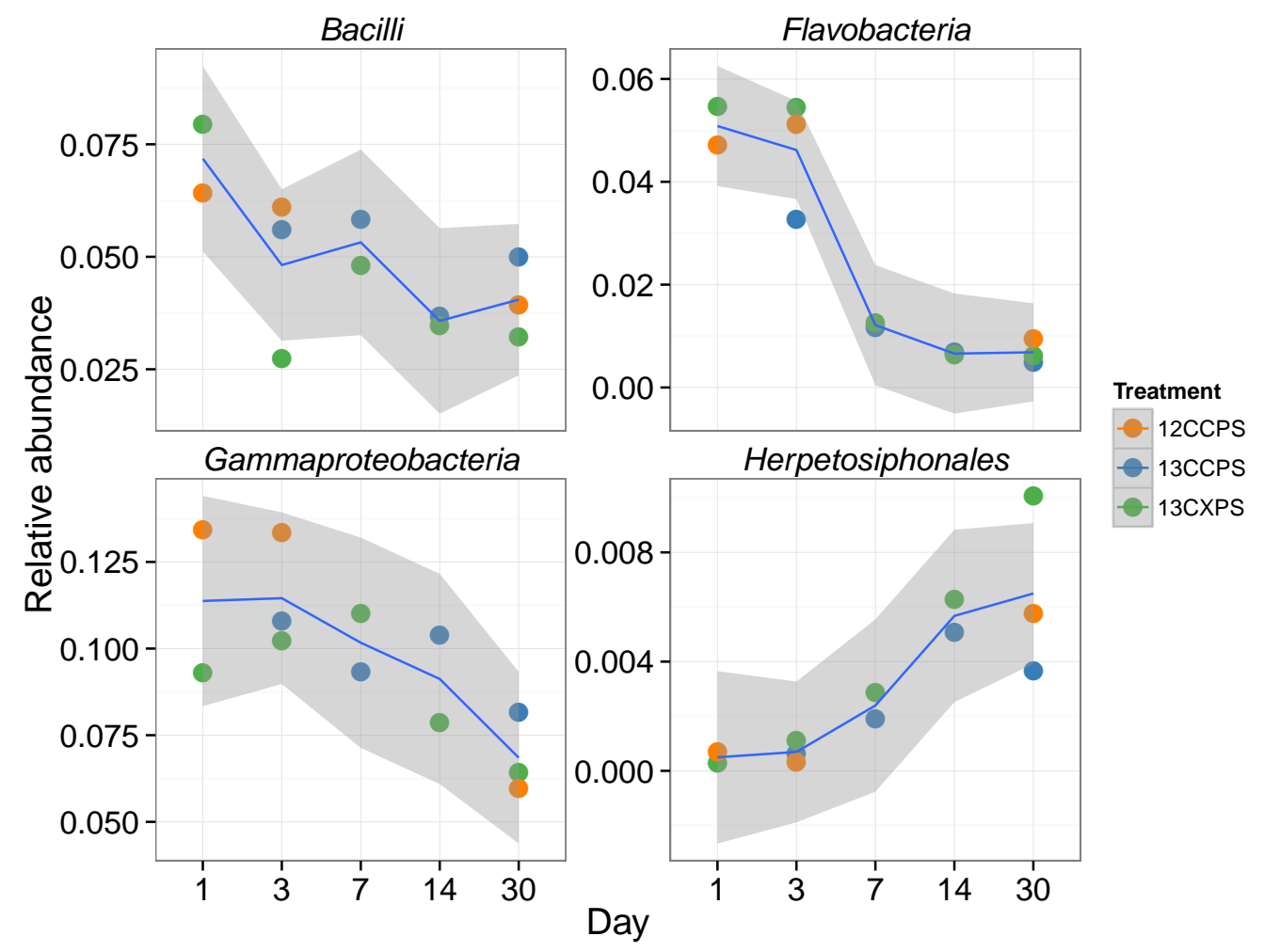

Fig. S5. Relative abundance in non-fractionated DNA versus time for classes that changed significantly. Samples from different treatments are labeled with different colors as indicated in the scale. Statistical analysis is presented in main text. 
bioRxiv preprint doi: https://doi.org/10.1101/022483; this version posted October 7, 2015. The copyright holder for this preprint (which was not certified by peer review) is the author/funder, who has granted bioRxiv a license to display the preprint in perpetuity. It is made

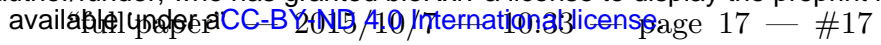
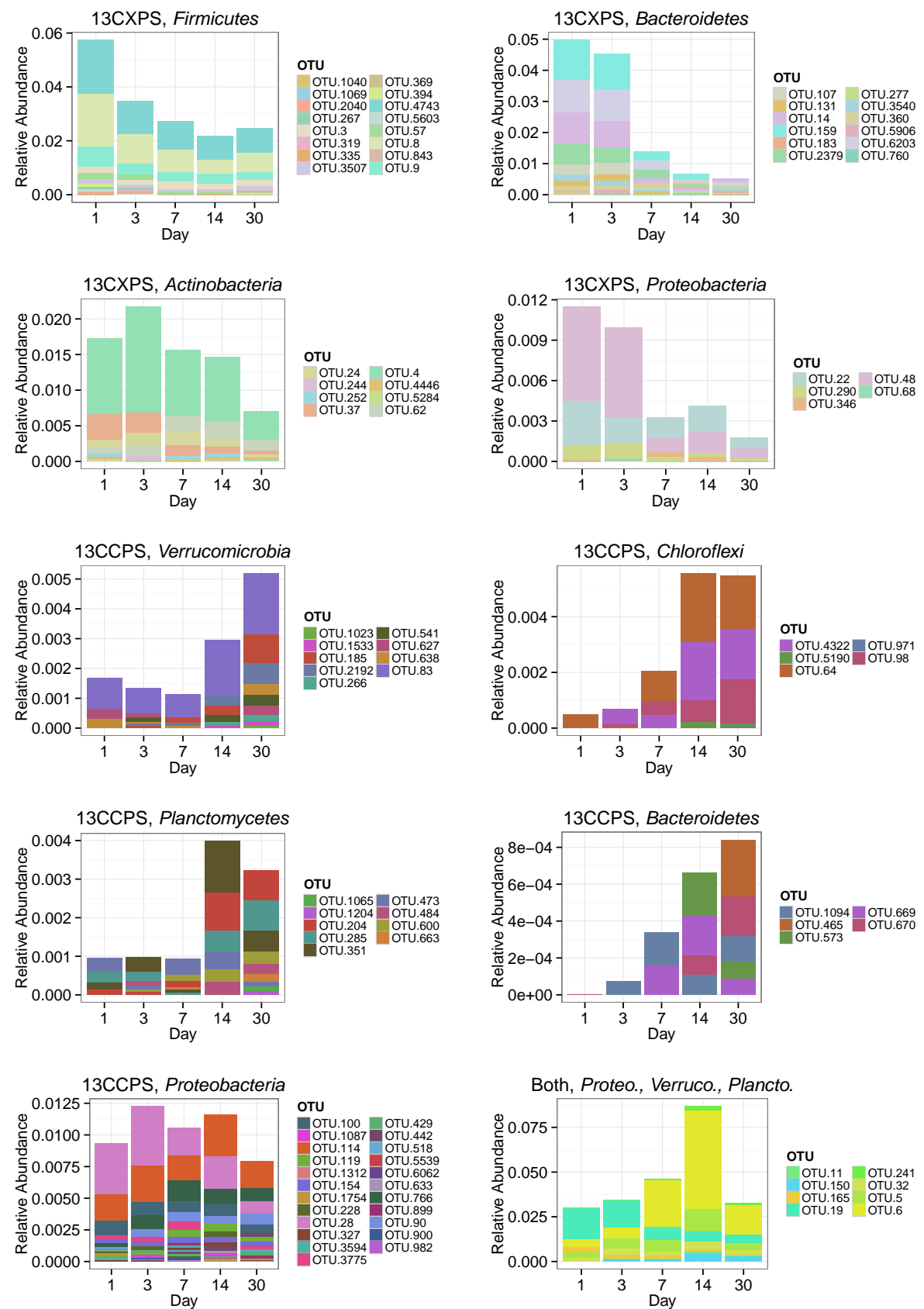

Fig. S6. Change in relative abundance in non-fractionated DNA over time for xylose responders (13CXPS) and cellulose responders (13CCPS). Each panel represents a responders to the indicated substrate (i.e. cellulose (13CCPS) or xylose (13CXPS)) within the indicated phylum except for the lower right panel which shows all reponders to both xylose and celluose. The abbreviations Proteo., Verruco., and Plancto., correspond to Proteobacteria, Verrucomicrobia, and Planctomycetes, respectively. 
bioRxiv preprint doi: https://doi.org/10.1101/022483; this version posted October 7, 2015. The copyright holder for this preprint (which was not certified by peer review) is the author/funder, who has granted bioRxiv a license to display the preprint in perpetuity. It is made

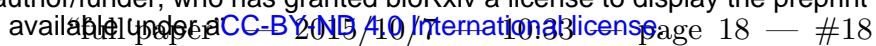

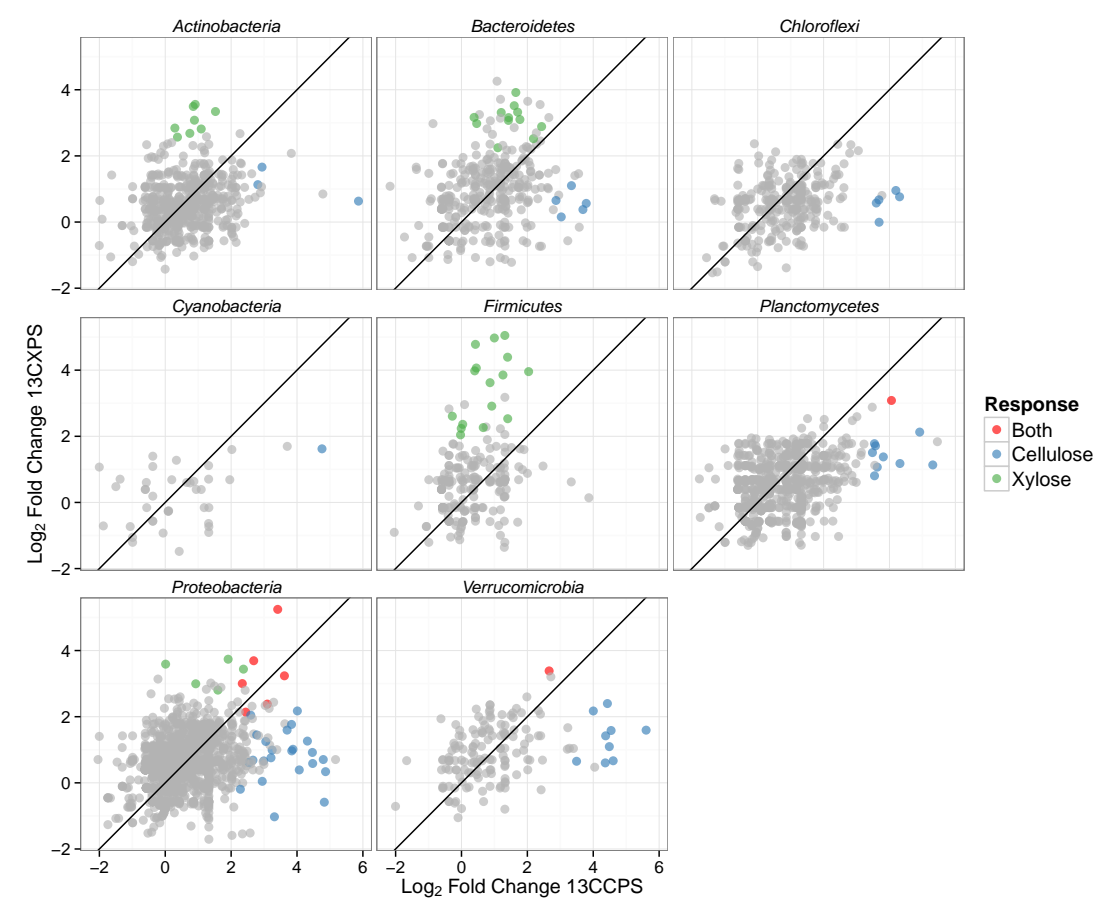

Fig. S7. Maximum enrichment at any point in time in high density fractions of ${ }^{13} \mathrm{C}$-treatments relative to control (expressed as LFC) shown for ${ }^{13} \mathrm{C}$-cellulose versus ${ }^{13} \mathrm{C}$-xylose treatments. Each point represents an OTU. Blue points are cellulose responders, green xylose responders, red are responders to both xylose and cellulose, and gray points are OTUs that did not respond to either substrate. Line indicates a slope of one.

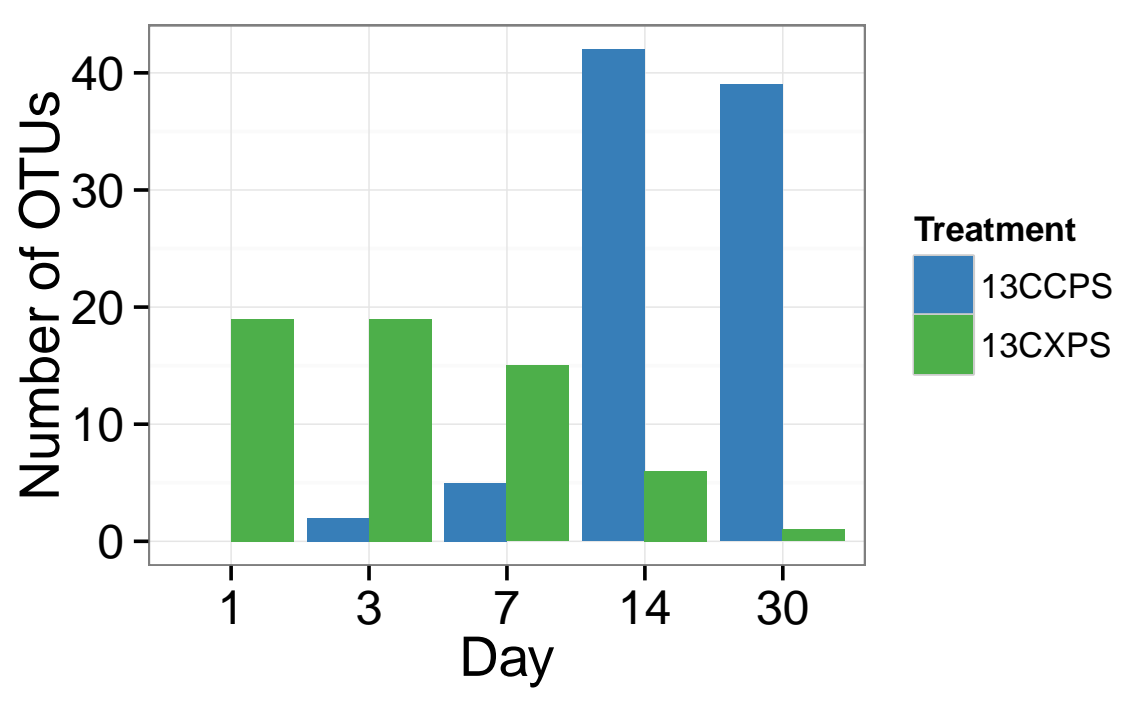

Fig. S8. Counts of xylose responders and cellulose responders over time. 
bioRxiv preprint doi: https://doi.org/10.1101/022483; this version posted October 7, 2015. The copyright holder for this preprint (which was not certified by peer review) is the author/funder, who has granted bioRxiv a license to display the preprint in perpetuity. It is made

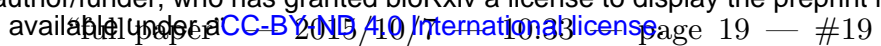
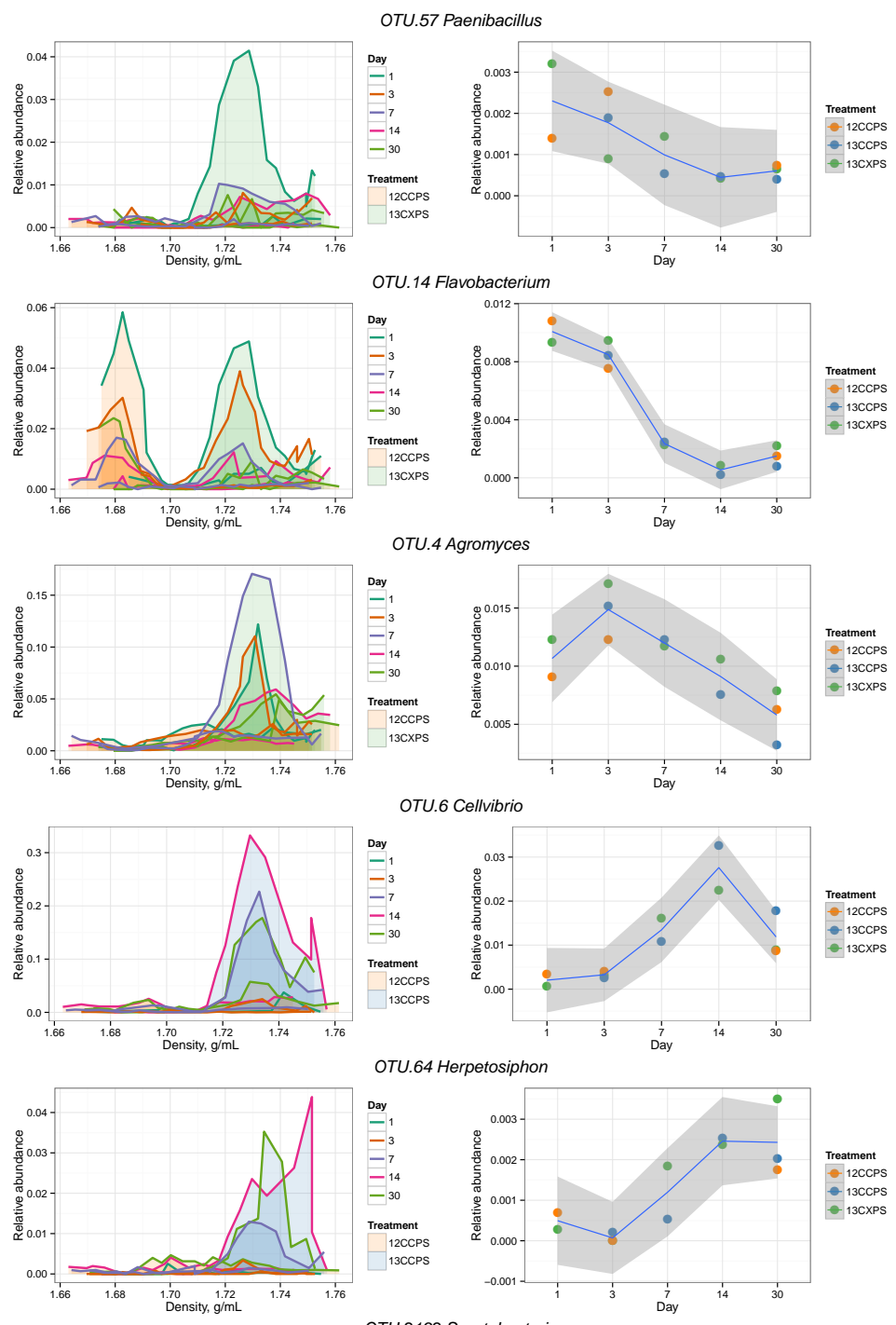

OTU.64 Herpetosiphon

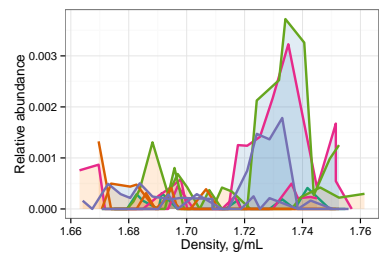

OTU.2192 Spartobacteria
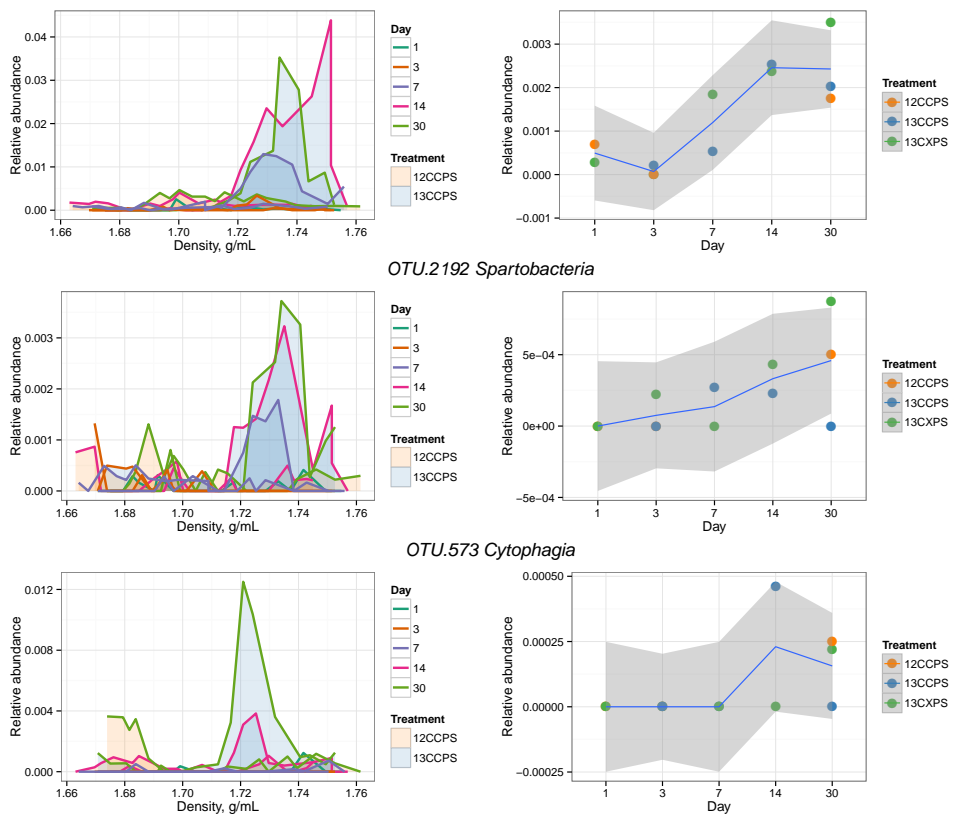

Fig. S9. Raw data from individual responders highlighted in the main text (see Results). The left column shows OTU relative abundance in density gradient fractions for the indicated treatment pair at each sampling point. Time is indicated by the line color (see legend). Gradient profiles are shaded to represent the different treatments where orange represents "control", blue " ${ }^{3}$ C-cellulose", and green " 13 C-xylose." The right column shows the relative abundance of each OTU in non-fractionated DNA. Enrichment in the high density fractions of ${ }^{13}$ C-treatments indicates an OTU likely has ${ }^{13}$ C-labeled DNA. 
bioRxiv preprint doi: https://doi.org/10.1101/022483; this version posted October 7, 2015. The copyright holder for this preprint (which was not certified by peer review) is the author/funder, who has granted bioRxiv a license to display the preprint in perpetuity. It is made

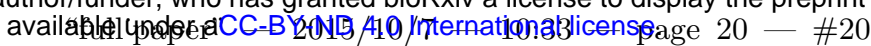

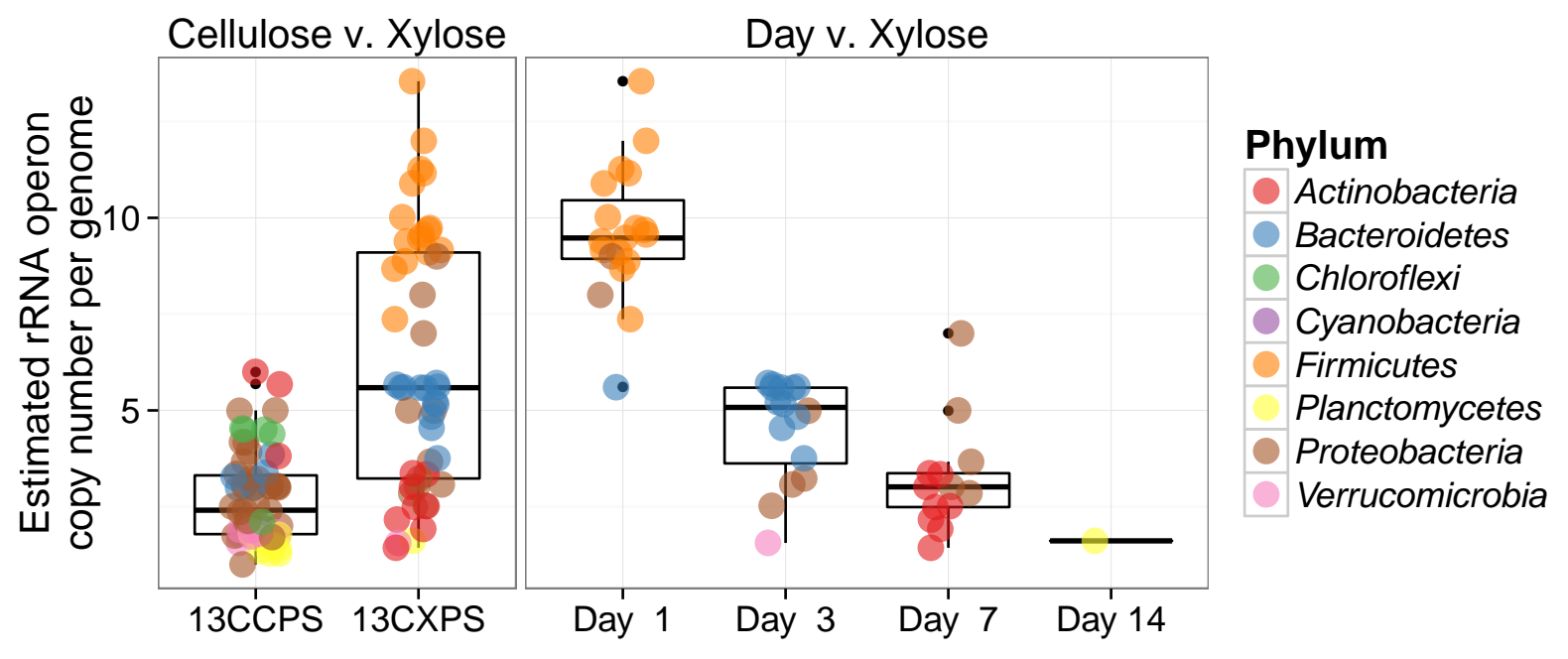

Fig. S10. Estimated $r r n$ copy number for xylose and cellulose responders. The leftmost panel contrasts estimated $r r n$ copy number for cellulose (13CCPS) and xylose (13CXPS) responders. The right panel shows estimated $r r n$ copy number versus time of first response for xylose responders. Colors denote the phylum of the OTUs (see legend).

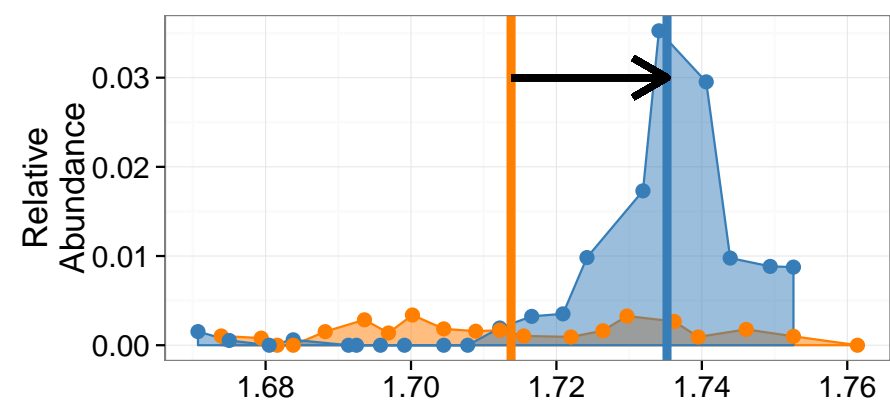

Density, $\mathrm{g} / \mathrm{mL}$

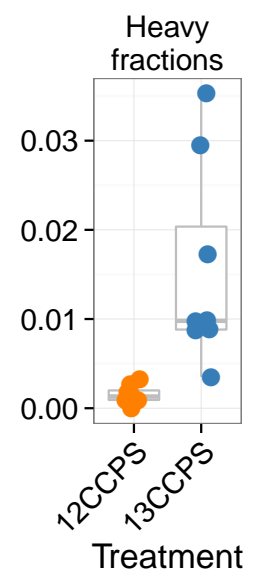

Fig. S11. Density profile for a single cellulose responder in the ${ }^{13} \mathrm{C}$-cellulose treatment (blue) and control (orange). Vertical lines show center of mass for each density profile and the arrow denotes the magnitude and direction of $\triangle \hat{B D}$. Right panel shows relative abundance values in the high density fractions (The boxplot line is the median value. The box spans one interquartile range (IR) about the median, whiskers extend 1.5 times the IR, and the dots indicate outlier values beyond 1.5 times the IR). 
bioRxiv preprint doi: https://doi.org/10.1101/022483; this version posted October 7, 2015. The copyright holder for this preprint (which was not certified by peer review) is the author/funder, who has granted bioRxiv a license to display the preprint in perpetuity. It is made

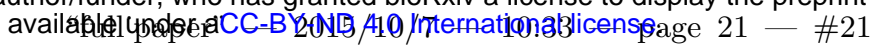

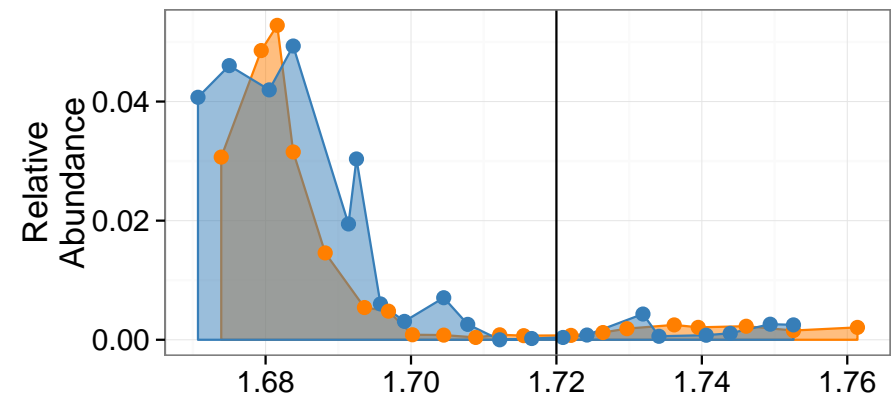

Density, $\mathrm{g} / \mathrm{mL}$

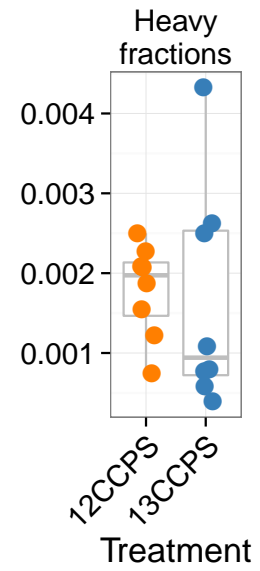

Fig. S12. Density profile for a single non-responder OTU. The ${ }^{13} \mathrm{C}$-cellulose treatment is in blue and the control treatment is in orange. The vertical line shows where high density fractions begin as defined in our analysis. The right panel shows relative abundance values in the high density fractions for each gradient (The boxplot line is the median value. The box spans one interquartile range (IR) about the median, whiskers extend 1.5 times the IR and the dots indicate outlier values beyond 1.5 times the IR). 
Table S1: ${ }^{13} \mathrm{C}$-xylose responders BLAST against Living Tree Project

\begin{tabular}{|c|c|c|c|c|c|c|}
\hline OTU ID & Fold change ${ }^{a}$ & Day $^{b}$ & All days ${ }^{c}$ & Top BLAST hits & $\%$ ID & Phylum;Class;Order \\
\hline OTU.1040 & 4.78 & 1 & 1 & Paenibacillus daejeonensis & 100.0 & Firmicutes Bacilli Bacillales \\
\hline OTU.1069 & 3.85 & 1 & 1 & Paenibacillus terrigena & 100.0 & Firmicutes Bacilli Bacillales \\
\hline OTU.11 & 5.25 & 7 & 7 & $\begin{array}{l}\text { Stenotrophomonas pavanii, } \\
\text { Stenotrophomonas maltophilia, } \\
\text { Pseudomonas geniculata }\end{array}$ & 99.54 & $\begin{array}{l}\text { Proteobacteria } \\
\text { Gammaproteobacteria } \\
\text { Xanthomonadales }\end{array}$ \\
\hline OTU.131 & 3.07 & 3 & 3 & $\begin{array}{l}\text { Flavobacterium fluvii, } \\
\text { Flavobacteria bacterium HMD1033, } \\
\text { Flavobacterium sp. HMD1001 }\end{array}$ & 100.0 & $\begin{array}{l}\text { Bacteroidetes Flavobacteria } \\
\text { Flavobacteriales }\end{array}$ \\
\hline OTU.14 & 3.92 & 3 & 1,3 & $\begin{array}{l}\text { Flavobacterium oncorhynchi, } \\
\text { Flavobacterium glycines, } \\
\text { Flavobacterium succinicans }\end{array}$ & 99.09 & $\begin{array}{l}\text { Bacteroidetes Flavobacteria } \\
\text { Flavobacteriales }\end{array}$ \\
\hline OTU.150 & 3.08 & 14 & 14 & $\begin{array}{l}\text { No hits of at least } 90 \% \\
\text { identity }\end{array}$ & 86.76 & $\begin{array}{l}\text { Planctomycetes Planctomycetacia } \\
\text { Planctomycetales }\end{array}$ \\
\hline OTU.165 & 2.38 & 3 & 3 & $\begin{array}{l}\text { Rhizobium skierniewicense, } \\
\text { Rhizobium vignae, } \\
\text { Rhizobium larrymoorei, } \\
\text { Rhizobium alkalisoli, } \\
\text { Rhizobium galegae, } \\
\text { Rhizobium huautlense }\end{array}$ & 100.0 & $\begin{array}{l}\text { Proteobacteria Alphaproteobacteria } \\
\text { Rhizobiales }\end{array}$ \\
\hline OTU.183 & 3.31 & 3 & 3 & $\begin{array}{l}\text { No hits of at least } 90 \% \\
\text { identity }\end{array}$ & 89.5 & $\begin{array}{l}\text { Bacteroidetes Sphingobacteriia } \\
\text { Sphingobacteriales }\end{array}$ \\
\hline OTU.19 & 2.14 & 7 & 7 & $\begin{array}{l}\text { Rhizobium alamii, } \\
\text { Rhizobium mesosinicum, } \\
\text { Rhizobium mongolense, } \\
\text { Arthrobacter viscosus, } \\
\text { Rhizobium sullae, } \\
\text { Rhizobium yanglingense, } \\
\text { Rhizobium loessense }\end{array}$ & 99.54 & $\begin{array}{l}\text { Proteobacteria Alphaproteobacteria } \\
\text { Rhizobiales }\end{array}$ \\
\hline OTU.2379 & 3.1 & 3 & 3 & $\begin{array}{l}\text { Flavobacterium pectinovorum, } \\
\text { Flavobacterium sp. CS100 }\end{array}$ & 97.72 & $\begin{array}{l}\text { Bacteroidetes Flavobacteria } \\
\text { Flavobacteriales }\end{array}$ \\
\hline OTU.24 & 2.81 & 7 & 7 & $\begin{array}{l}\text { Cellulomonas aerilata, } \\
\text { Cellulomonas humilata, } \\
\text { Cellulomonas terrae, } \\
\text { Cellulomonas soli, } \\
\text { Cellulomonas xylanilytica }\end{array}$ & 100.0 & $\begin{array}{l}\text { Actinobacteria Micrococcales } \\
\text { Cellulomonadaceae }\end{array}$ \\
\hline OTU.241 & 3.38 & 3 & 3,14 & $\begin{array}{l}\text { No hits of at least } 90 \% \\
\text { identity }\end{array}$ & 87.73 & $\begin{array}{l}\text { Verrucomicrobia Spartobacteria } \\
\text { Chthoniobacterales }\end{array}$ \\
\hline OTU.244 & 3.08 & 7 & 7 & $\begin{array}{l}\text { Cellulosimicrobium funkei, } \\
\text { Cellulosimicrobium terreum }\end{array}$ & 100.0 & $\begin{array}{l}\text { Actinobacteria Micrococcales } \\
\text { Promicromonosporaceae }\end{array}$ \\
\hline OTU.252 & 3.34 & 7 & 7 & Promicromonospora thailandica & 100.0 & $\begin{array}{l}\text { Actinobacteria Micrococcales } \\
\text { Promicromonosporaceae }\end{array}$ \\
\hline OTU.267 & 4.97 & 1 & 1 & $\begin{array}{l}\text { Paenibacillus pabuli, } \\
\text { Paenibacillus tundrae, } \\
\text { Paenibacillus taichungensis, } \\
\text { Paenibacillus xylanexedens, } \\
\text { Paenibacillus xylanilyticus }\end{array}$ & 100.0 & Firmicutes Bacilli Bacillales \\
\hline OTU.277 & 3.52 & 3 & 3 & Solibius ginsengiterrae & 95.43 & $\begin{array}{l}\text { Bacteroidetes Sphingobacteriia } \\
\text { Sphingobacteriales }\end{array}$ \\
\hline
\end{tabular}


Table S1 - continued from previous page

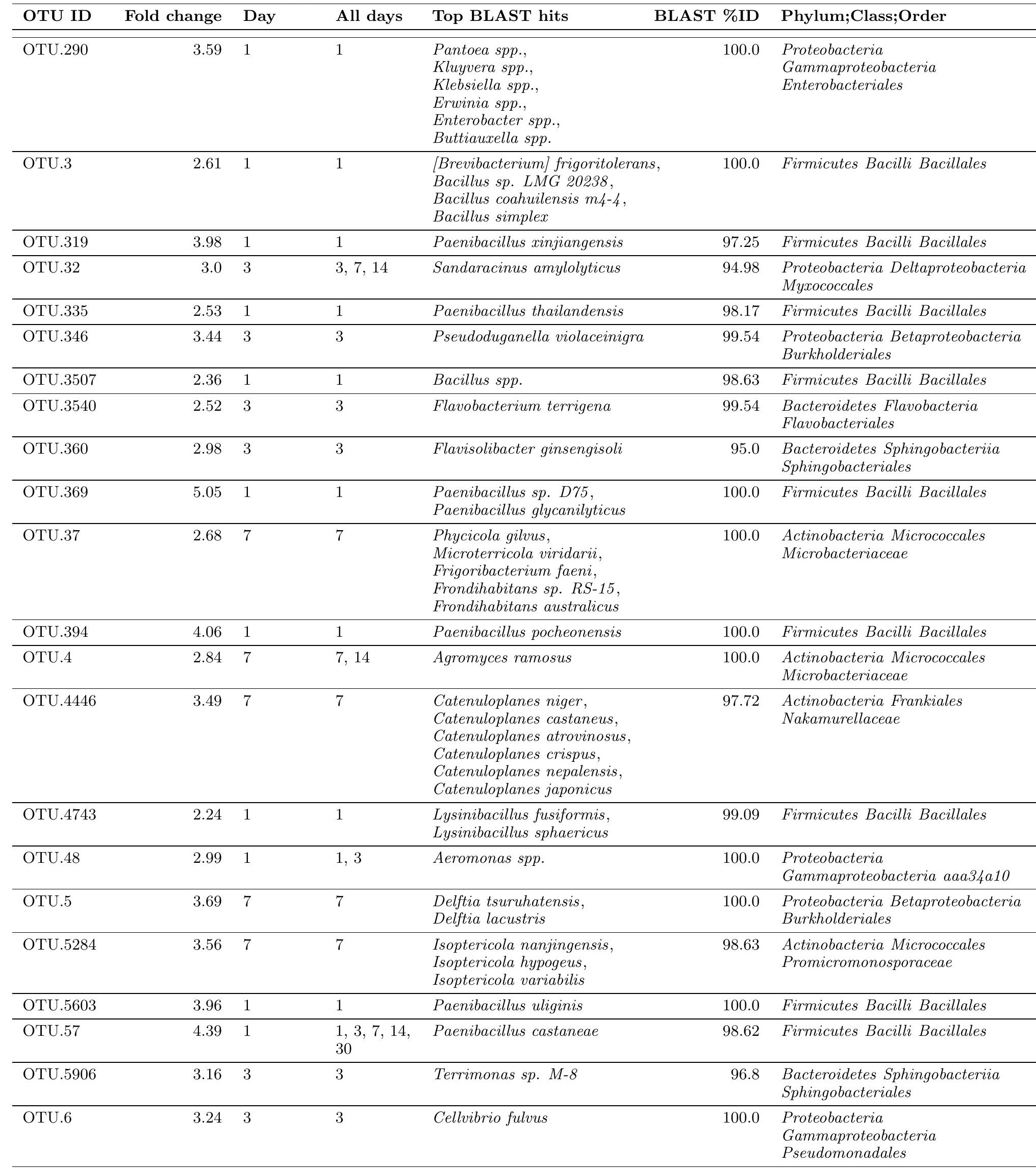


bioRxiv preprint doi: https://doi.org/10.1101/022483; this version posted October 7, 2015. The copyright holder for this preprint (which was not certified by peer review) is the author/funder, who has granted bioRxiv a license to display the preprint in perpetuity. It is made

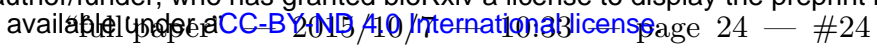

Table S1 - continued from previous page

\begin{tabular}{|c|c|c|c|c|c|c|}
\hline OTU ID & Fold change & Day & All days & Top BLAST hits & BLAST \%ID & Phylum;Class;Order \\
\hline OTU.62 & 2.57 & 7 & 7 & Nakamurella flavida & 100.0 & $\begin{array}{l}\text { Actinobacteria Frankiales } \\
\text { Nakamurellaceae }\end{array}$ \\
\hline OTU.6203 & 3.32 & 3 & 3 & $\begin{array}{l}\text { Flavobacterium granuli, } \\
\text { Flavobacterium glaciei }\end{array}$ & 100.0 & $\begin{array}{l}\text { Bacteroidetes Flavobacteria } \\
\text { Flavobacteriales }\end{array}$ \\
\hline OTU.68 & 3.74 & 7 & 7 & $\begin{array}{l}\text { Shigella flexneri, } \\
\text { Escherichia fergusonii, } \\
\text { Escherichia coli, } \\
\text { Shigella sonnei }\end{array}$ & 100.0 & $\begin{array}{l}\text { Proteobacteria } \\
\text { Gammaproteobacteria } \\
\text { Enterobacteriales }\end{array}$ \\
\hline OTU.760 & 2.89 & 3 & 3 & Dyadobacter hamtensis & 98.63 & $\begin{array}{l}\text { Bacteroidetes Cytophagia } \\
\text { Cytophagales }\end{array}$ \\
\hline OTU.8 & 2.26 & 1 & 1 & Bacillus niacini & 100.0 & Firmicutes Bacilli Bacillales \\
\hline OTU.843 & 3.62 & 1 & 1 & Paenibacillus agarexedens & 100.0 & Firmicutes Bacilli Bacillales \\
\hline OTU.9 & 2.04 & 1 & 1 & $\begin{array}{l}\text { Bacillus megaterium, } \\
\text { Bacillus flexus }\end{array}$ & 100.0 & Firmicutes Bacilli Bacillales \\
\hline
\end{tabular}

\footnotetext{
${ }^{\text {a }}$ Maximum observed $\log _{2}$ of fold change.

b Day of maximum fold change.

c All response days.
} 
Table S2: ${ }^{13}$ C-cellulose responders BLAST against Living Tree Project

\begin{tabular}{|c|c|c|c|c|c|c|}
\hline OTU ID & Fold change $^{a}$ & Day $^{b}$ & All days ${ }^{c}$ & Top BLAST hits & $\%$ ID & Phylum;Class;Order \\
\hline OTU.100 & 2.66 & 14 & 14 & $\begin{array}{l}\text { Pseudoxanthomonas sacheonensis, } \\
\text { Pseudoxanthomonas dokdonensis }\end{array}$ & 100.0 & $\begin{array}{l}\text { Proteobacteria } \\
\text { Gammaproteobacteria } \\
\text { Xanthomonadales }\end{array}$ \\
\hline OTU.1023 & 4.61 & 30 & 30 & $\begin{array}{l}\text { No hits of at least } 90 \% \\
\text { identity }\end{array}$ & 80.54 & $\begin{array}{l}\text { Verrucomicrobia Spartobacteria } \\
\text { Chthoniobacterales }\end{array}$ \\
\hline OTU.1065 & 5.31 & 14 & 14,30 & $\begin{array}{l}\text { No hits of at least } 90 \% \\
\text { identity }\end{array}$ & 84.55 & $\begin{array}{l}\text { Planctomycetes Planctomycetacia } \\
\text { Planctomycetales }\end{array}$ \\
\hline OTU.1087 & 4.32 & 14 & 14,30 & $\begin{array}{l}\text { Devosia soli, } \\
\text { Devosia crocina, } \\
\text { Devosia riboflavina }\end{array}$ & 99.09 & $\begin{array}{l}\text { Proteobacteria Alphaproteobacteria } \\
\text { Rhizobiales }\end{array}$ \\
\hline OTU.1094 & 3.69 & 30 & 30 & Sporocytophaga myxococcoides & 99.55 & $\begin{array}{l}\text { Bacteroidetes Cytophagia } \\
\text { Cytophagales }\end{array}$ \\
\hline OTU.11 & 3.41 & 14 & 14 & $\begin{array}{l}\text { Stenotrophomonas pavanii, } \\
\text { Stenotrophomonas maltophilia, } \\
\text { Pseudomonas geniculata }\end{array}$ & 99.54 & $\begin{array}{l}\text { Proteobacteria } \\
\text { Gammaproteobacteria } \\
\text { Xanthomonadales }\end{array}$ \\
\hline OTU.119 & 3.31 & 14 & 14,30 & Brevundimonas alba & 100.0 & $\begin{array}{l}\text { Proteobacteria Alphaproteobacteria } \\
\text { Caulobacterales }\end{array}$ \\
\hline OTU.120 & 4.76 & 14 & 14,30 & Vampirovibrio chlorellavorus & 94.52 & $\begin{array}{l}\text { Cyanobacteria SM1D11 } \\
\text { uncultured-bacterium }\end{array}$ \\
\hline OTU.1204 & 4.32 & 30 & 30 & Planctomyces limnophilus & 91.78 & $\begin{array}{l}\text { Planctomycetes Planctomycetacia } \\
\text { Planctomycetales }\end{array}$ \\
\hline OTU.1312 & 4.07 & 30 & 30 & Paucimonas lemoignei & 99.54 & $\begin{array}{l}\text { Proteobacteria Betaproteobacteria } \\
\text { Burkholderiales }\end{array}$ \\
\hline OTU.132 & 2.81 & 14 & 14 & Streptomyces spp. & 100.0 & $\begin{array}{l}\text { Actinobacteria Streptomycetales } \\
\text { Streptomycetaceae }\end{array}$ \\
\hline OTU.150 & 4.06 & 14 & 14 & $\begin{array}{l}\text { No hits of at least } 90 \% \\
\text { identity }\end{array}$ & 86.76 & $\begin{array}{l}\text { Planctomycetes Planctomycetacia } \\
\text { Planctomycetales }\end{array}$ \\
\hline OTU.154 & 3.24 & 14 & 14 & $\begin{array}{l}\text { Pseudoxanthomonas mexicana, } \\
\text { Pseudoxanthomonas japonensis }\end{array}$ & 100.0 & $\begin{array}{l}\text { Proteobacteria } \\
\text { Gammaproteobacteria } \\
\text { Xanthomonadales }\end{array}$ \\
\hline OTU.165 & 3.1 & 14 & 14 & $\begin{array}{l}\text { Rhizobium skierniewicense, } \\
\text { Rhizobium vignae, } \\
\text { Rhizobium larrymoorei, } \\
\text { Rhizobium alkalisoli, } \\
\text { Rhizobium galegae, } \\
\text { Rhizobium huautlense }\end{array}$ & 100.0 & $\begin{array}{l}\text { Proteobacteria Alphaproteobacteria } \\
\text { Rhizobiales }\end{array}$ \\
\hline OTU.1754 & 4.48 & 14 & 14 & $\begin{array}{l}\text { Asticcacaulis biprosthecium, } \\
\text { Asticcacaulis benevestitus }\end{array}$ & 96.8 & $\begin{array}{l}\text { Proteobacteria Alphaproteobacteria } \\
\text { Caulobacterales }\end{array}$ \\
\hline OTU.185 & 4.37 & 14 & 14,30 & $\begin{array}{l}\text { No hits of at least } 90 \% \\
\text { identity }\end{array}$ & 85.14 & $\begin{array}{l}\text { Verrucomicrobia Spartobacteria } \\
\text { Chthoniobacterales }\end{array}$ \\
\hline OTU.19 & 2.44 & 14 & 14 & $\begin{array}{l}\text { Rhizobium alamii, } \\
\text { Rhizobium mesosinicum, } \\
\text { Rhizobium mongolense, } \\
\text { Arthrobacter viscosus, } \\
\text { Rhizobium sullae, } \\
\text { Rhizobium yanglingense, } \\
\text { Rhizobium loessense }\end{array}$ & 99.54 & $\begin{array}{l}\text { Proteobacteria Alphaproteobacteria } \\
\text { Rhizobiales }\end{array}$ \\
\hline
\end{tabular}


Table S2 - continued from previous page

\begin{tabular}{|c|c|c|c|c|c|c|}
\hline OTU ID & Fold change & Day & All days & Top BLAST hits & BLAST \%ID & Phylum;Class;Order \\
\hline OTU.2192 & 3.49 & 30 & 14,30 & $\begin{array}{l}\text { No hits of at least } 90 \% \\
\text { identity }\end{array}$ & 83.56 & $\begin{array}{l}\text { Verrucomicrobia Spartobacteria } \\
\text { Chthoniobacterales }\end{array}$ \\
\hline OTU.228 & 2.54 & 30 & 30 & Sorangium cellulosum & 98.17 & $\begin{array}{l}\text { Proteobacteria Deltaproteobacteria } \\
\text { Myxococcales }\end{array}$ \\
\hline OTU.241 & 2.66 & 14 & 14 & $\begin{array}{l}\text { No hits of at least } 90 \% \\
\text { identity }\end{array}$ & 87.73 & $\begin{array}{l}\text { Verrucomicrobia Spartobacteria } \\
\text { Chthoniobacterales }\end{array}$ \\
\hline OTU.257 & 2.94 & 14 & 14 & $\begin{array}{l}\text { Lentzea waywayandensis, } \\
\text { Lentzea flaviverrucosa }\end{array}$ & 100.0 & $\begin{array}{l}\text { Actinobacteria Pseudonocardiales } \\
\text { Pseudonocardiaceae }\end{array}$ \\
\hline OTU.266 & 4.54 & 30 & 14,30 & $\begin{array}{l}\text { No hits of at least } 90 \% \\
\text { identity }\end{array}$ & 83.64 & $\begin{array}{l}\text { Verrucomicrobia Spartobacteria } \\
\text { Chthoniobacterales }\end{array}$ \\
\hline OTU.28 & 2.59 & 14 & 14 & $\begin{array}{l}\text { Rhizobium giardinii, } \\
\text { Rhizobium tubonense, } \\
\text { Rhizobium tibeticum, }\end{array}$ & 99.54 & $\begin{array}{l}\text { Proteobacteria Alphaproteobacteria } \\
\text { Rhizobiales }\end{array}$ \\
\hline
\end{tabular}

\section{Rhizobium tibeticum,}

Rhizobium mesoamericanum CCGE 501,

Rhizobium herbae,

Rhizobium endophyticum

\begin{tabular}{|c|c|c|c|c|c|c|}
\hline OTU.285 & 3.55 & 30 & 14,30 & Blastopirellula marina & 90.87 & $\begin{array}{l}\text { Planctomycetes Planctomycetacia } \\
\text { Planctomycetales }\end{array}$ \\
\hline OTU.32 & 2.34 & 3 & 3 & Sandaracinus amylolyticus & 94.98 & $\begin{array}{l}\text { Proteobacteria Deltaproteobacteria } \\
\text { Myxococcales }\end{array}$ \\
\hline OTU.327 & 2.99 & 14 & 14 & $\begin{array}{l}\text { Asticcacaulis biprosthecium, } \\
\text { Asticcacaulis benevestitus }\end{array}$ & 98.63 & $\begin{array}{l}\text { Proteobacteria Alphaproteobacteria } \\
\text { Caulobacterales }\end{array}$ \\
\hline OTU.351 & 3.54 & 14 & 14,30 & Pirellula staleyi DSM 6068 & 91.86 & $\begin{array}{l}\text { Planctomycetes Planctomycetacia } \\
\text { Planctomycetales }\end{array}$ \\
\hline OTU.3594 & 3.83 & 30 & 30 & Chondromyces robustus & 90.41 & $\begin{array}{l}\text { Proteobacteria Deltaproteobacteria } \\
\text { Myxococcales }\end{array}$ \\
\hline OTU.3775 & 3.88 & 14 & 14 & $\begin{array}{l}\text { Devosia glacialis, } \\
\text { Devosia chinhatensis, } \\
\text { Devosia geojensis, } \\
\text { Devosia yakushimensis }\end{array}$ & 98.63 & $\begin{array}{l}\text { Proteobacteria Alphaproteobacteria } \\
\text { Rhizobiales }\end{array}$ \\
\hline OTU.429 & 3.7 & 30 & 14,30 & $\begin{array}{l}\text { Devosia limi, } \\
\text { Devosia psychrophila }\end{array}$ & 97.72 & $\begin{array}{l}\text { Proteobacteria Alphaproteobacteria } \\
\text { Rhizobiales }\end{array}$ \\
\hline OTU.4322 & 4.19 & 14 & $7,14,30$ & $\begin{array}{l}\text { No hits of at least } 90 \% \\
\text { identity }\end{array}$ & 89.14 & $\begin{array}{l}\text { Chloroflexi Herpetosiphonales } \\
\text { Herpetosiphonaceae }\end{array}$ \\
\hline OTU.442 & 3.05 & 30 & 30 & Chondromyces robustus & 92.24 & $\begin{array}{l}\text { Proteobacteria Deltaproteobacteria } \\
\text { Myxococcales }\end{array}$ \\
\hline OTU.465 & 3.79 & 30 & 30 & Ohtaekwangia kribbensis & 92.73 & $\begin{array}{l}\text { Bacteroidetes Cytophagia } \\
\text { Cytophagales }\end{array}$ \\
\hline OTU.473 & 3.58 & 14 & 14 & Pirellula staleyi DSM 6068 & 90.91 & $\begin{array}{l}\text { Planctomycetes Planctomycetacia } \\
\text { Planctomycetales }\end{array}$ \\
\hline OTU.484 & 4.92 & 14 & 14,30 & $\begin{array}{l}\text { No hits of at least } 90 \% \\
\text { identity }\end{array}$ & 89.09 & $\begin{array}{l}\text { Planctomycetes Planctomycetacia } \\
\text { Planctomycetales }\end{array}$ \\
\hline OTU.5 & 2.69 & 14 & 14 & $\begin{array}{l}\text { Delftia tsuruhatensis, } \\
\text { Delftia lacustris }\end{array}$ & 100.0 & $\begin{array}{l}\text { Proteobacteria Betaproteobacteria } \\
\text { Burkholderiales }\end{array}$ \\
\hline OTU.518 & 4.8 & 14 & 14 & Hydrogenophaga intermedia & 100.0 & $\begin{array}{l}\text { Proteobacteria Betaproteobacteria } \\
\text { Burkholderiales }\end{array}$ \\
\hline OTU.5190 & 3.6 & 30 & 14,30 & $\begin{array}{l}\text { No hits of at least } 90 \% \\
\text { identity }\end{array}$ & 88.13 & $\begin{array}{l}\text { Chloroflexi Herpetosiphonales } \\
\text { Herpetosiphonaceae }\end{array}$ \\
\hline OTU.541 & 4.49 & 30 & 30 & $\begin{array}{l}\text { No hits of at least } 90 \% \\
\text { identity }\end{array}$ & 84.23 & $\begin{array}{l}\text { Verrucomicrobia Spartobacteria } \\
\text { Chthoniobacterales }\end{array}$ \\
\hline OTU.5539 & 4.01 & 14 & 14 & Devosia subaequoris & 98.17 & $\begin{array}{l}\text { Proteobacteria Alphaproteobacteria } \\
\text { Rhizobiales }\end{array}$ \\
\hline OTU.573 & 3.03 & 30 & 30 & Adhaeribacter aerophilus & 92.76 & $\begin{array}{l}\text { Bacteroidetes Cytophagia } \\
\text { Cytophagales }\end{array}$ \\
\hline
\end{tabular}


Table S2 - continued from previous page

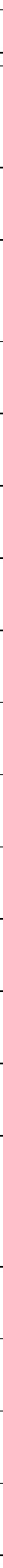

\footnotetext{
${ }^{\mathrm{a}}$ Maximum observed $\log _{2}$ of fold change.

$\mathrm{b}$ Day of maximum fold change.

c All response days.
} 